Palaeohispanica 2, (2002), pp. 227-269

\title{
CLAUDIO ELIANO Y EL FUNERAL DESCARNATORIO EN CELTIBERIA: REFLEXIONES CRÍTICAS A PROPÓSITO DE Sobre la naturaleza de los animales, $\mathrm{X}, 22$
}

\author{
Gabriel Sopeña Genzor \\ Vicente Ramón Palerm*
}

\begin{abstract}
"Al cabo de los siglos, este tratado es a la vez irresponsable y gratísimo": así se expresaba Jorge Luis Borges en el breve prólogo que habilitó en 1987 para la edición en español de Sobre la naturaleza de los animales. En efecto, no hay estudio que deje de señalar la levedad de Claudio Eliano, autor plenamente inscrito en la corriente paradoxográfica de los siglos II y III d.C., ávida de evasión y muy poco afecta a comprometer el tiempo y el esfuerzo de sus lectores. Eliano declara en su prólogo y en su epílogo que deseaba divertir, agradar, y, a su manera, instruir. Pero su liviandad, tendencia a mirificar y falta de brillantez son tales que permiten destacar como mejor acierto de la obra que aquí nos

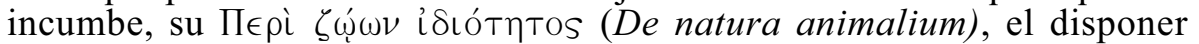
de una idea consistente, una que acrisola la insólita yuxtaposición de anécdotas reunidas con desconcertante aliño. Esto es: la Razón universal informa todo lo existente, ergo el comportamiento animal está dotado de virtud, aunque irracional; y prueba la existencia de un sistema moral que dimana de la Naturaleza.

Su profunda y robusta fe estoica como argumento fundamental, por lo tanto. Es verdad que gracias a él preservamos fragmentos de obras antiguas y nombres de autores que de otro modo hubiesen desaparecido, destacándose su discreto sello en la literatura posterior; y no resulta des-
\end{abstract}

\footnotetext{
* Los autores desean expresar su gratitud a Alberto Bernabé (Universidad Complutense de Madrid), Mercedes Cabello (Biblioteca Marqués de Valdecilla, Madrid), Carmen Guiral (UNED, Madrid), Enrique Ariño (Universidad de Salamanca), Silvia Alfayé, Francisco Beltrán, Ana Isabel Magallón y Francisco Marco Simón (Universidad de Zaragoza).

${ }^{1}$ Además de su Sobre la naturaleza de los animales — de donde procede el fragmento que aquí analizaremos - conocemos de Claudio Eliano sus Historias diversas (edición de HERCHER, R., 1866, con versión en francés de LUKINOVICH, A. - MORAND, A.F., 1991), unas Cartas rústicas (editadas en español con estudio crítico por BARRIO VEGA, M ${ }^{\mathrm{a}}$ L., del, 1999), dos epigramas (KAIBEL, G., 1878, números 1084-1085) y fragmentos de dos

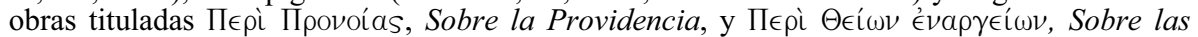
evidencias divinas (en HERCHER, R., 1866, vol. 2, pp. 190-283). Su alegato contra Heliogábalo, titulado Contra Gymnis y citado por Filóstrato, está definitivamente perdido.
} 
deñable que su amor discipular por Pausanias haya contribuido a que éste fuese apreciado por la posteridad. En fin, labor compiladora y dilección por el maestro son sin duda cualidades estimables, pero todavía insuficientes para que el historiador actual no sea precavido frente a este sofista nacido en Preneste en el siglo II d.C., exquisitamente bilingüe y sumo sacerdote pontifical que, a decir de su contemporáneo Flavio Filóstrato (Vit. Sof., II, 31), fue varón culto y honrado que consagró su celibato a los estudios. ${ }^{2}$

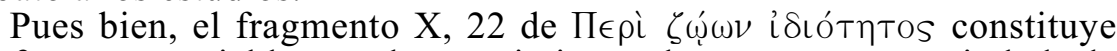
una fuente apreciable en el conocimiento de un aspecto capital de la religiosidad indígena de la Hispania antigua: el ritual de exposición cadavérica, especialísima práctica cargada de sentido ético que, como lo demuestran incontrovertiblemente los cientos de evidencias minuciosamente analizadas a lo largo de los últimos veinte años, fue verificada en toda la Céltica con unas connotaciones sacrificiales en los antípodas mismos del mundo griego y latino. ${ }^{3}$ Esta es, desde luego, la peor parado-

\footnotetext{
${ }^{2}$ Sobre Claudio Eliano no existe abundante literatura específica. Léase un sólido estado de la cuestión, reciente y con bibliografía muy completa, en KINDSTRAND, J.F., 1997, donde el autor demuestra su poderoso dominio sobre la materia. Hay alusiones, lógicamente, en los mejores compendios de literatura griega; pero, en general, no mejoran la autoridad enciclopédica de LESKY, A., 1976 (1963), pp. 885 y ss. o, más recientemente, de BOWIE, E.L., 1985, pp. 680-682. Por supuesto, son útiles las introducciones de DÍAZ-REGAÑ́N, J.M. (1984) y VARA DONADO, J. (1989) a las ediciones críticas existentes en español (hay otra versión, sin estudio ni glosa alguna, de OTERO, $\mathrm{M}^{\mathrm{a}}$., 1987 — con brevísimo prólogo de Borges-, con mero afán de divulgación). REARDON, B.P., 1971, pp. 225-226, 240-241 y 273-275, resulta todavía de provechoso estudio, inscribiendo al autor en las corrientes de su tiempo. Para completar esta visión de conjunto del periodo se revelan también útiles REARDON, B.P., 1974, pp. 23-29 y KENNEDY, G., 1972. Y son valiosas las notas de GÓMEZ ESPELOSÍN, F.J., 1996 acerca del género paradoxográfico, siguiendo de cerca, en lo que compete a Eliano, el célebre trabajo de GIANNINI, A., 1964. En fin, es brillante la exposición de ANDERSON, G., 1993 (que supone una revisión del clásico trabajo de BOWERSOCK, G.W., 1969).

${ }^{3}$ Una primera defensa de la coherencia céltica del funeral en ámbito celtibérico fue realizada por SOPEÑA, G., 1987. A ella siguió un análisis extenso de los problemas de adecuación textual, iconográfica y arqueológica atendiendo con todo detalle a Europa y a las Islas, que debe examinarse en SOPEÑA, G., 1995, passim, especialmente capítulo III. En lo alusivo a la Céltica continental, el ritual descarnatorio no cesa de brindar datos de enorme interés y espectacularidad. Como doctrina más reciente, resulta útil el resumen - muy extenso- de BRUNAUX, J-L. et alii, 1999, acerca de Ribemont, con toda suerte de apreciaciones; y, por supuesto, alusiones a otros ejemplos europeos. Éstos se hallarán también en el volumen editado por WIELAND, G., 1999 - cuyas planchas 14 a 16 resultan, por cierto, muy ilustrativas-, con adecuada bibliografía. Igualmente, es de utilidad LAMBOT, B., 1998. En lo tocante a las Islas Británicas, recúrrase a la autoridad de la profesora GREEN, M.A., 2001, con descripción de los más significados ejemplos, bibliografía actualizada y adecuada revisión de los planteamientos. CARR, G. - KNÜSEL, C., 1997, consiguen ofrecer una rápida visión de conjunto (si bien pasando de puntillas sobre la hondura del concepto sacrificial de los rituales descarnatorios célticos); y PARKER PEARSON, M., 2000, constituye, igualmente, una aproximación concisa (con hincapié en aspectos teóricos y, en ocasiones, alguna pérdida de visión en relación al continente). En fin, resulta sobresaliente la aportación de MARCO SIMÓN, F., 1999. En Celtiberia, la excavación de la necrópolis de Numancia -cuyo material óseo se está estudiando a fondo- ha proporcionado ya nociones de sumo relieve, insinuadas desde luego como tónica en el conjunto de indicios necropolitanos celtibéricos (cf. SOPEÑA, G., 1995, pp. 243-262). De tal modo, el trabajo del equipo del profesor Alfredo Jimeno está revelando la uniformidad de los restos humanos depositados en las tumbas. Escasos y correspondientes sólo a zonas craneales y huesos largos, revelan una acción intencionada, abriendo esclarecedoras perspectivas en las prácticas rituales crematorias y expositorias, existiendo
} 
ja que debe arrostrar siempre el estudioso de las religiones indígenas de nuestra península: la carencia de testimonios referidos a las esferas de mentalidad de estas poblaciones resulta de una gravedad inconsolable. Ello, lógicamente, agiganta la importancia de un autor discreto como Eliano.

Precisamente por ello, en lo tocante a los textos referidos a Hispania, resulta completamente imprescindible la revisión rigurosa y en profundidad de ciertos planteamientos y la invitación a transitar por nuevas vías, por cuanto con harta frecuencia no han existido análisis en un siglo de investigación. Lamentablemente, resulta de justicia reconocer que en demasiadas ocasiones el punto único de apoyo de algunas posturas sigue siendo la autoridad indiscutida - ya que no indiscutible - de quien las acunó por vez primera y su repetición, cómoda y acrítica.

Por lo tanto, dando cumplimiento al compromiso adquirido en un estudio anterior, ${ }^{4}$ y perseverando en una línea de investigación que iniciamos hace años, ${ }^{5}$ este artículo pretende analizar el fragmento $\mathrm{X}, 22$ del De natura animalium de Claudio Eliano. A ello nos aplicaremos de inmediato, procediendo a exponer las características del problema al que nos enfrentamos.

\section{HISTORIA DE LAS INVESTIGACIONES}

Adolf Schulten ordenaba ya en su Numantia de 1914 el discurso que, hasta hoy mismo, ha constituido communis opinio. El catedrático de Erlangen - sin conceder ni el texto en griego, ni su traducción en alemán - es rotundo en su decreto y no consiente ninguna duda: según afirma Claudio Eliano, los vacceos ${ }^{6}$ exponen a los muertos en combate a los buitres, a los que creen sagrados. Páginas después - por cierto, con una palmaria errata en sus notas a pie de página- insiste en su precepto al aludir al capital fragmento de Silio Itálico (Punica, III, 340-43, al cual esta vez sí cede, adjuntándolo en latín pero sin tolerar traducción propia) alusivo a los celtíberos. Esta aseveración quedaría establecida ya como doctrina compacta en las Fontes Hispaniae Antiquae (FHA) sin desvelar argumento alguno, ni contrastar su sentencia; y, evidentemente, sin re-

\footnotetext{
además un porcentaje muy alto de sepulcros que sólo contienen restos de fauna, lo que hace pensar en enterramientos simbólicos, condicionados, obviamente, por la imposibilidad de recuperar el cuerpo del difunto (JIMENO, A., 1996; 1999 y 2001, pp. 246-247; IDEM et alii, 1996). Al hilo de las evidencias apuntadas, en el resto de la Hispania céltica también comienza a plantearse la posibilidad de que el rito - quizá por influjo celtibérico- hubiera sido practicado (aunque la ausencia de material necropolitano suficiente obliga a caminar con toda la cautela posible y a ser sumamente puntilloso con las hipótesis). Así, véase para el territorio vetón la fundamentada opinión de ÁLVAREZ SANCHÍS, J. R., 1999, p. 310; y pp. 169 y ss. e IDEM, 2001, pp. 259-277. (cf., sin embargo, SALINAS DE FRÍAS, M., 2001, pp. 139 у ss.). Acerca de los cántabros, con mayor levedad argumental, PERALTA, E., 2000, p. 175 y 230-231. En lo tocante a los vacceos, SANZ MÍNGUEZ, C., 1998, pp. 479, 488 y, sobre todo, pp. 491-495, 532-33. Para otros ámbitos hispanos, los problemas e indicios relativos al rito han sido excelentemente planteados por RUÍZ ZAPATERO, G. - LORRIO, A., 1995 y MARCO SIMÓN, F., 1998, pp. 392-395 (cf., complementariamente, ALFAYÉ VILLA, S., I 2001 , pp. 62 y ss. y passim).

${ }^{4}$ SOPEÑA, G., 1995 , p. 219 y nota 46.

${ }^{5}$ SOPEÑA, G. - RAMÓN PALERM, V., 1994.

${ }^{6}$ La cursiva es nuestra.
} 
signarse a ninguna autoridad bibliográfica. ${ }^{7}$

El período posterior a la guerra de 1936 impuso una severa neutralización política que pulverizó la antigua y fecunda tradición liberal española, dejando vía expedita a posiciones como la de Schulten, privilegiada por el Régimen: nacionalista, hiperbólica, estrechamente esencialista, racista y determinista. Como se ha señalado en magníficos estudios recientes, los años cuarenta del siglo XX fueron testigos de la clausura de cualquier alternativa de renovación teórica, de un proceso de paulatina desarticulación de las disciplinas históricas y -en lo alusivo a la Historia Antigua- de una lamentable aporía: al menos hasta muy bien ganada la década de los setenta, las fuentes literarias fueron acatadas - jamás revisadas o contestadas - desde la ortodoxia de las Fontes Hispaniae Antiquae, gobernadas por Adolf Schulten. ${ }^{8}$

Obviamente, el fragmento que ahora nos ocupa se inscribió en tal panorama desde su formulación "oficial"; y ello hasta hoy mismo. En el ámbito de aporía descrito, la información fue repetida sin revisar el texto, creándose un verdadero tópico historiográfico que procede poner de manifiesto.

El maestro Blas Taracena, al aludir al funeral descarnatorio entre los celtíberos, también lo hizo extensivo a los vacceos, atribuyendo la afirmación a Claudio Eliano. Ello quedó escrito en su excelente aportación de 1954 a la Historia de España, dirigida por Menéndez Pidal, obra clave en la historia de las investigaciones. ${ }^{9}$ Por su parte, Federico Wattenberg, en su clásico trabajo sobre los habitantes del Duero, asumió sin más la opinión de Schulten, sometiéndose absolutamente a la autoridad

\footnotetext{
${ }^{7}$ SCHULTEN, A., 1914, pp. 149 y 199 (el error está en que la nota 8 debe corresponder a la 7, y viceversa). Cf. FHA, tomo VIII, 1959. pp. 221 y, especialmente, 330-331.

${ }^{8}$ Como se sabe, la colección Fontes Hispaniae Antiquae fue editada en la Ciudad Condal bajo el mando de Schulten desde 1922, quien siempre la consideró conquista exclusiva: suya es la responsabilidad última de los textos y los comentarios allí vertidos. En el impulso editorial, como representación de la Universidad de Barcelona, tuvo al lado a Bosch (tomos II y III, 1925 y 1935) y luego a Pericot (volumen IV de 1937). Exiliado el primero (cf. la biografía que Schulten pergeñó para mayor gloria de sí mismo en 1953: Bosch sufre una infamante damnatio memoriae), los libros V y VI, de 1940 y 1952, tuvieron la compañía de Pericot, siempre bajo la jefatura del alemán. La presentación de Joan Maluquer al tomo VII, editado en 1987 (sesenta y cinco años después de su previsión inicial) resulta, desde la distancia, elocuente y recomendable. La preparación de las entregas VIII - la que aquí nos compete- y IX le fue encajada a un subordinado de Schulten, Roberto Grosse - quien, por cierto, como confirma el profesor BALIL, A., 1976, p. 15, no tuvo a bien poner su pie en España-, "que pudo mandar los textos con grandes dificultades" (FHA, VII, p. XII). Muchas debieron ser, puesto que el tomo IX fue editado en 1947 y el VIII en 1959, poniendo el nombre en ambos Pericot y Rubio, bajo el caudillaje y maniobra del teutón. Huelga decir que en ambos libros imperan tanto el desaforado personalismo de Schulten en todos los ámbitos cuanto el silencio o ignorancia (¿habría quizá que decir desprecio?) de la bibliografía de autores peninsulares. Respecto al período e individuo descritos, resultan imprescindibles PASAMAR ALZURIA, G., 1991, passim (pp.174-79, 245-50, 253-258; y especialmente cap. VII, y pp. 307 y ss.) y GARCÍA QUINTELA, M.V., 1990 y, 1991. Igualmente, véase de modo más particularizado DUPLÁ, A., 1993; TORRE ECHÁVARRI, J.I., de la, 1998; PEIRÓ MARTÍN, I. PASAMAR ALZURIA, G., 1989-90; CRUZ ANDREOTTI, G., 1991; y OLMOS,R., 1991.

${ }^{9}$ TARACENA, B., 1954, pp. 257, 282, 288. Taracena, sin embargo, ya había atribuido a los vacceos el rito mencionado por Eliano, al aludir al uso entre los celtíberos en su tesis doctoral de 1924, aportando traducción (IDEM, 1924, p. 48 y nota 1).
} 


\section{Claudio Eliano y el funeral descarnatorio en Celtiberia...}

germánica sin ningún otro pormenor, aportación textual o detalle bibliográfico $;{ }^{10}$ y posteriormente, en su libro sobre la cerámica de Numancia, se adhirió igualmente a la opinión de Caro y Blázquez. ${ }^{11}$

Julio Caro Baroja, en su obra de 1946 Los pueblos de España, no alude a la cita de Eliano, aunque sí reflexionó acerca del funeral de exposición de los celtíberos. ${ }^{12}$ La razón es el poco crédito que concede al escritor prenestino, como declaraba casi de soslayo en 1943, sin aportar otros argumentos de mayor relieve. ${ }^{13}$ Por último, en su fundamental estudio de 1962 el profesor José María Blázquez estableció un espacio para reflexionar acerca del rito descarnatorio en Celtiberia. Siguiendo en lo fundamental a Caro, planteaba paralelos con persas, medos y otros pueblos de Asia y África de tendencias pastoriles; y, atribuyendo de nuevo la práctica citada por Eliano a los vacceos, expresaba su extrañeza acerca del uso entre estas gentes, a causa de su carácter eminentemente agrícola, achacándola a influjo numantino. ${ }^{14} \mathrm{La}$ obra de Blázquez, jalón ineludible de la investigación acerca de las mentalidades indígenas, ha sido la pauta repetida hasta la década de los ochenta, sin aportaciones de mayor entidad.

En fin, los estudios más recientes - ante las incontestables evidencias desveladas por los arqueólogos acerca de la extensión universal de este funeral en la Céltica toda - aluden a Eliano, si bien para matizar el hecho cierto de que la práctica está perfectamente ilustrada por el verbo antiguo - también por la iconografía- en Hispania. Es el proceder, por ejemplo, de Martín Almagro, García Quintela, Lorrio, Marco y Sopeña. ${ }^{15}$

\footnotetext{
${ }^{10}$ WATTENBERG, F., 1959 , p. 15 y notas 73 y 74 . El autor se limita a atribuir el rito a los vacceos, de manera brevísima, citando simplememente a Schulten.

${ }^{11}$ Recordando la posibilidad de que la formación del pueblo arévaco pudiese haber sido debida a la fuerza transmisora de las estepas asiáticas, el autor traía a colación las informaciones de Eliano y Silio Itálico para sostener su aserto, sobre la base de que el funeral tenía origen oriental y conexiones escitas. WATTENBERG, F., 1963, p. 59, nota 29; cf. pp. 61 y ss. La idea, en efecto, no es suya y ya había sido anticipada por Caro Baroja y Blázquez (cf. SOPEÑA, G., 1995, pp. 211-212).

${ }^{12}$ CARO BAROJA, J., 1985 (1946), vol, 1, p. 309 y nota 136.

13 “.(...) La costumbre de dejar a los muertos expuestos para que los despedacen los buitres, algún autor de poco crédito lo refiere como cosa propia de los vacceos". CARO BAROJA, J., 1986 (1943), p. 63.

${ }^{14}$ BLÁZQUEZ, J.M., 1962, pp. 12-13. La opinión del autor se ha mantenido en su fecunda obra posterior (por ejemplo, 1975, p. 182; 1983, pp. 227 y 265-266; 1991, pp. 257-58). Apréciese su matización de 1978 (p. 111): "Eliano (Hist. An., 10, 22), autor de poco crédito, hace extensiva a los vacceos la costumbre propia de los pueblos pastores de dejar a la intemperie los cuerpos caídos en la lucha, de lo que no se pueden sacar conclusiones sobre la economía vaccea, pues probablemente se trate de una confusión con los celtíberos".

${ }^{15}$ Como más recientes aportaciones, consúltense ALMAGRO GORBEA, M., 2001, p. 100; GARCÍA QUINTELA, M.V., 2001, p. 37; LORRIO, A., 1997, pp. 345-36 y 348; MARCO SIMÓN, F., 1999, p. 5; SOPEÑA, G., 1995, pp. 212 y 219. Paradójicamente, las obras alusivas específicamente al ámbito vacceo suelen ser remisas con la referencia. El debate entre los historiadores del área actualmente adopta más bien la forma de controversia entre quienes consideran a este pueblo como celtibérico - vetusta idea de Cabré, Santa Olalla o Wattenberg (con el cariz ideológico de una preeminencia exclusiva y excluyente de la Meseta/Castilla, en el fondo) - o, tal y como los muestran las fuentes sistemáticamente, como un ámbito meridianamente diferenciado (véanse adecuados estados de la cuestión en ROMERO, F. - SANZ, C. - ESCUDERO, Z., 1993, volumen con contribuciones sustanciales; ROMERO
} 
Consiguientemente, el caudillaje científico de Schulten había incoado la afirmación tópica que postula: los vacceos exponen a sus caídos en bata1la, y esto lo dice Claudio Eliano. Tal afirmación es, sencillamente, falsa. Inadmisiblemente, el teutón le adjudica al sofista romano la paternidad de una opinión ajena a éste, puesto que la tradición manuscrita es unánime: jamás se alude a los vacceos, siempre a unos Bapкaîol.

El comportamiento de Schulten, en este sentido, resulta inaudito. En efecto, en las FHA se procedió a la ocultación de esta evidencia esencial, de la que el autor era perfectamente consciente ya en 1955:

"Los celtíberos creían, por tanto, según Silio, que los buitres transportaban los restos de los guerreros al cielo, al lado de los dioses (...). Según Eliano, también los vacceos,${ }^{16}$ parientes y aliados de los celtíberos en la región central del Duero, tenían esta misma costumbre. Dice en De

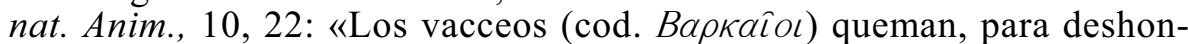
rarles, los cadáveres de los muertos por enfermedad, por morir cobarde y débilmente, pero a los caídos en la guerra, como héroes, los echan a los buitres, a los que adoran como animales sagrados». También en este caso puede ser la argumentación añadidura del autor". ${ }^{17}$

Alusión entre paréntesis y sin mayor explicación al término que contemplan los códices con unanimidad, anotación del término vacceos en cursiva, publicación de todo ello en una obra editada en Estrasburgo y en alemán cuatro años antes que en España, definitivo acallamiento posterior del hecho desde las $F H A \ldots{ }^{18}$

CARNICERO, F. - SANZ, C., 1997, sucinto. Asimismo, constituyen aportaciones básicas SACRISTÁN DE LAMA, J.D., 1997, BURILLO, F., 1998, pp. 201-205 y LORRIO, A., 2000 , p. 110). Sea como fuere, se ha debido lidiar aquí con el casi total desconocimiento del mundo funerario hasta fecha reciente (cf. ahora RUIZ VÉLEZ, I., 2001); y así GonzálezCobos Dávila, en el primer trabajo de conjunto realizado desde Wattenberg, no hace desde luego ninguna alusión a De natura animalium (GONZÁLEZ-COBOS DÁVILA, A. M ${ }^{\mathrm{a}}$, 1989). Por su parte, SANZ MÍNGUEZ, C. (1998), en su magnífico estudio de la necrópolis de las Ruedas (Padilla de Duero, Valladolid), a tenor de las evidencias arqueológicas, plantea la posibilidad de que — como sucede entre los celtíberos, y acaso por su influjo directo- los vacceos vivieran una ética agonística, culminada con un ritual diferente de tipo expositorio (p. 445), pero no menciona a Eliano; y, cuando divide el comportamiento funerario en prácticas normativas y no normativas alude al texto de Silio Itálico, no al del prenestino (p. 479). Finalmente, estableciendo la posibilidad de que en el Duero medio hubiera habido gran mortandad durante el periodo de confrontación con Roma, vuelve a aludir a Silio Itálico y al funeral descarnatorio de los vecinos celtíberos (p. 495). Sin embargo, en su aportación de 2001 en colaboración con Martín Valls, Sanz, al plantear las evidencias de un ritual tripartito en el área vaccea (cremación, inhumación infantil y exposición) sí aporta el texto de Eliano (SANZ MÍNGUEZ, C. - MARTíN VALLS, R., 2001,p. 323). Ya entregadas las presentes páginas a la imprenta, hemos recibido el estudio de GOMEZ FRAILE, J.M., Los celtas en los valles altos del Duero y del Ebro, Alcalá de Henares, 2001. Allí, en las notas 153 y 162 -aunque sin discusión crítica de los testimonios-, se detecta el problema de transmisión textual que aquí analizamos.

${ }^{16}$ En cursiva en el original.

${ }^{17}$ La traducción es la de la edición española de 1959, pp. 517-518.

${ }^{18}$ Debe ser destacado que la traducción del libro Iberische Landeskunde, de 1955, apareció con el título Geografía y etnografía antiguas de la Península Ibérica en 1959, coincidiendo con la aparición del tomo VIII de las $F H A$. Sobra añadir que éstas últimas tuvieron una repercusión y manejo mucho mayores que aquél, llegando a eclipsar su cita de inmediato en las obras especializadas (al respecto, cf. GARCİA QUINTELA, M.V., 1990, p. 191, nota 41). 
Más aún, Schulten sigue en exclusiva la versión de $\Pi \epsilon \rho i \zeta ~ \zeta \omega ̣ \omega \nu$

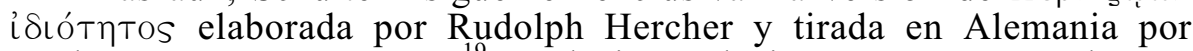
Teubner entre 1864 y1866. ${ }^{19}$ Es decir, exclusivamente a través de esta edición, a limine y presentándola como propia sin empacho, el profesor de Erlangen se limita a sancionar una mera conjetura introducida por Samuel Bochart (1599-1667), pastor protestante que, entre otras altas disciplinas, cultivó la zoología: esos Варкаîou acaso fueren Ваккаîol. En su habitual posición decimonónica de relajación frente a la tradición manuscrita, Hercher había dejado ya fijada esta forma Bakкaîo -que traduce en latín Baccaei- en la edición que él mismo realizase en París para Ambroise F. Didot en 1858, mucho más completa desde luego que la suya posterior de Leizpig. ${ }^{20}$

Esta asombrosa actitud de Adolf Schulten resulta especialmente grave, considerando el olvido y proscripción que ha sufrido la figura de Joaquín Costa en relación a las disciplinas históricas. Es él sin duda el auténtico pionero de los estudios acerca de la religión indígena hispana, habiendo constituido la clave de arranque de los investigadores posteriores aun cuando, hasta la década de los noventa del siglo XX, casi todos ellos hayan ignorado la paternidad de las opiniones del montisonense. El polígrafo aragonés, sin ser estrictamente un historiador, dejó sólidamente planteados los cimientos para el estudio de las estructuras ideológicas peninsulares, desde perspectivas interdisciplinares y generosa amplitud de objetivos: no operó jamás al margen de lo certificado en su tiempo, buscando y citando autoridad donde la hubo y manifestando siempre una honradez científica intachable. El duro proceso de selección ideológica al que ya hemos aludido privilegió a Schulten, entre otros, hasta el estrago: autores como Bosch Gimpera fueron solapados y Joaquín Costa fue expulsado al olvido puro. La deuda con él es inmensa, pero no ha sido saldada todavía: sus observaciones, en rigor, o han sido meramente repetidas durante más de cien años sin citar su autoría, o bien han sido de

\footnotetext{
${ }^{19}$ FHA, 1959, tomo VIII, p. XVII.

${ }^{20}$ Por cuanto suele abstenerse de enmendar a Hercher —al que se ciñe en su versión de 186466 (la misma que sigue Schulten, por tanto) - , es bien significativa la duda que Scholfield evita reprimir en su edición de 1958 para The Loeb Classical Library. En su volumen II de

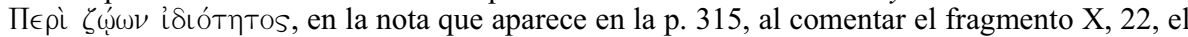
autor - que traduce, efectivamente, vaccaei- advierte: "If Bаккаîо is correctly rendered "vaccaei", they were a tribe in the NW of Spain". En la parte griega, sobre el término Bakкaîo, Scholfield anota al pie la procedencia de tal conjetura: "Bochart: Варкаîou" (SCHOLFIELD, A.F., 1958, p. 315). En fin, nos parece sumamente elocuente el silencio de un editor pulcro como J. Zwicker, en obra de manifiesta trascendencia como lo es Fontes Historiae Religionis Celticae (la cual, por cierto, por más que Schulten la ignore, ya era clásica en su época. ZWICKER, J., 1934). Allí, por ejemplo, se incluye el fragmento de la Descripción de Grecia (X, 21, 3) en el que Pausanias, maestro de Eliano, describe el hondo estupor que causó a los griegos que los gálatas dejaran como pábulo de los buitres a los cadáveres de sus combatientes (pp. 75-76); y se alude también a la cita de Silio Itálico (Pun, III, 340-43) en relación al comentado rito entre los celtíberos (p. 60); y también, como corresponde al carácter de compendio de la obra del editor, se recogen cuantos testimonios acerca de la espiritualidad celta aparecen en la Varia Historia de Claudio Eliano (p. 87). Sin embargo, sintomáticamente Zwicker omite la referencia acerca de los Варкаîol, a quienes él no identifica como vacceos: no da por seguro lo que sólo supone la conjetura de Samuel Bochart frente a la unanimidad de la tradición manuscrita.
} 
gran ayuda por su lucidez y modernidad. ${ }^{21}$

Es el caso del problema que aquí retomamos, pues fue Costa, en efecto, quien dejaba esbozada la cuestión en 1895, por más que haya sido absolutamente incógnita hasta ahora. Al efectuar su traducción del texto de Claudio Eliano, el oscense proponía: "Los Barcaeos, gente de la Hesperia (...)"; y, en nota al pie, apostillaba:

"Ningún otro autor menciona tal tribu de Bapкaîo en España. En la edición de Gronovio (Basilea, 1750) opina uno de los anotadores, Daniel Wilhelm Triller, que ha de leerse Bakkaîo , (...) y corresponde á los vaccaei de Plinio, ahora Tierra de Campos". ${ }^{22}$

\section{El TeXto de Claudio Eliano: ReVisión CRítica}

En efecto, una mínima atención al texto de Eliano - por somera que sea - transluce la realidad de una redacción delicada, comprometida, cuya exégesis se revela de importancia para la comprensión capaz del problema que aquí presentamos (y, en cualquier caso, para la verificación de un debate que deseamos fructífero en el seno de la historiografía clásica sobre fuentes paleohispánicas). Con las observaciones que siguen en el presente epígrafe, pretendemos demostrar que el análisis combinado de los datos, especialmente en el ámbito textual, orienta al escepticismo crítico en lo concerniente a la tradición historiográfica glosada en las anteriores líneas. De este modo, y tras presentar el fragmento correspondiente, nos atendremos aquí a una argumentación basada en las líneas matrices que a continuación citamos, en consideración tanto extrínseca como intrínseca del texto valorado: la competencia históricoliteraria y lingüística de Eliano; las vicisitudes ecdóticas que De natura animalium ha experimentado; el problema textual inherente al pasaje capital de nuestro estudio.

El texto que facilita Eliano indica expresamente (Sobre la naturaleza de los animales $\mathrm{X}, 22):{ }^{23}$

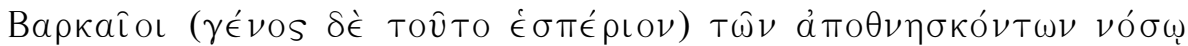

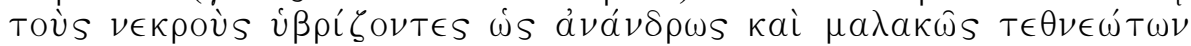

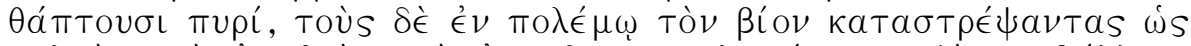

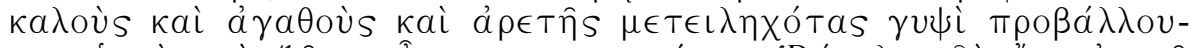

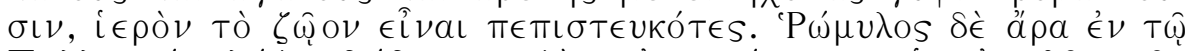

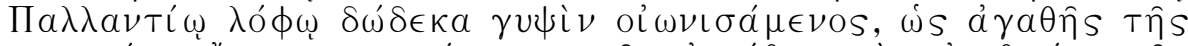

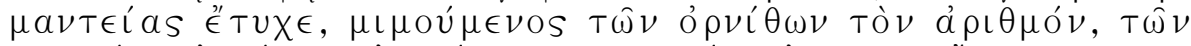

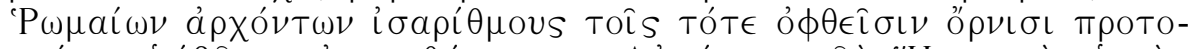

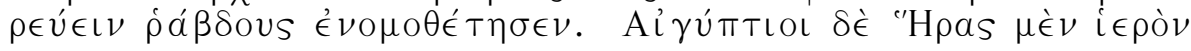

\footnotetext{
${ }^{21}$ Véase en profundidad GARCÍA QUINTELA, M.V., 1990, 1991; SOPEÑA, G., 1995, pp. 23 y ss. y passim.

${ }^{22}$ COSTA, J., 1895 (1917), p. 155 y nota 1.

${ }^{23}$ Seguimos inicialmente la más reciente edición de Scholfield con una excepción: adoptamos la lectura Bapкaîos, que la transmisión textual ha legado de forma unánime, frente a la conjetura de Bochart Ваккаîo que, como ya hemos anticipado, el propio Scholfield (cf. la nota del editor ad loc.) concede sin demasiado entusiasmo. Por otra parte, la traducción que presentamos es nuestra.
} 


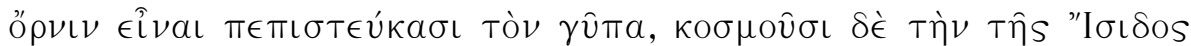

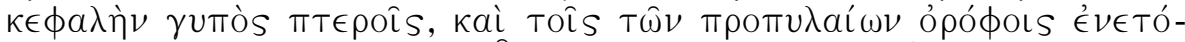

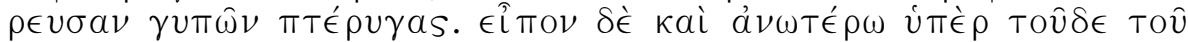

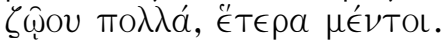

"Los barceos (un pueblo occidental) vilipendian los cadáveres de quienes han muerto por enfermedad y los exponen al fuego porque, en su opinión, han tenido una muerte de cobarde molicie. Sin embargo, a quienes dan su vida en la guerra los tienen por gallardos, nobles, de natural valerosos, y los arrojan a los buitres en la creencia de que éstos son animales sagrados. Como es sabido, cuando, en la colina del Palatino, Rómulo presagió un augurio favorable a la vista de doce buitres, decretó - por analogía al número de las aves - que los mandatarios de los romanos fueran antecedidos de un número de lictores equivalente al de las aves entonces observadas. Por su parte, los egipcios creen firmemente que el buitre es un ave consagrada a Hera, adornan la cabeza de Isis con plumas de buitre y en los techos de los propíleos graban unas alas de buitre. Ya he ofrecido con anterioridad una cumplida documentación aunque de índole distinta - sobre este animal".

El fragmento en cuestión ilustra efectivamente, de modo paradigmático, el tenor de Eliano como literato y las contingencias que ha sufrido la tradición ecdótica relativa a Sobre la naturaleza de los animales. He aquí un escritor grecorromano, cuyo calificativo de sofista debe interpretarse en un sentido que el término destila en el siglo II d.C., a saber, la pura acepción de estudioso. Este prenestino, que nació hacia el 170 d.C., ${ }^{24}$ se afanó en el estudio y en la práctica escriptoria del griego, con un estilo que, como ha sido señalado, prima la sencillez ( $\alpha \dot{\phi} \in \dot{\lambda} \epsilon \iota \alpha$ ) en el seno de un aticismo convencional. ${ }^{25}$. Tal circunstancia se aviene al procedimiento linguístico de la Segunda Sofística, círculo en que nuestro autor debe ser inscrito por escuela y vocación. No es objeto del presente artículo la paráfrasis - que se antojaría redundante respecto de estudios precedentes - sobre las fuentes manejadas y el modo literario de cierto desaliño que nuestro autor acredita. ${ }^{26 .}$ Pero es justo reseñar la combina-

\footnotetext{
${ }^{24} \mathrm{Si}$ bien ignoramos con exactitud sus fechas de nacimiento y muerte, Claudio Eliano vivió en el último tercio del siglo II y la primera mitad del III d.C. Filóstrato (Vit. Sof., II, 31) informa de que nuestro autor fue discípulo de Pausanias, quien se hizo cargo de la cátedra de Retórica en Roma al fallecer el titular, Herodes Ático: ello acaeció en 177 d.C. La Suda afirma que Eliano ejerció la profesión a continuación de Adriano el Sofista, muerto en 193 d.C. El emperador Septimio Severo falleció en 211 d.C. y su esposa Julia Domna - a cuyo círculo perteneció Eliano - lo hizo en 217 d.C. Por último, de nuevo Flavio Filóstrato refiere que nuestro escritor compuso un colérico alegato contra Heliogábalo tras la muerte de éste, ocurrida en 222 d.C. En fin, sabemos que sobrepasó los sesenta años. Con todo ello, Lesky propone unas fechas entre el 175-235 d.C y Arnaud-Lindet entre el 170-240 d.C. (LESKY, A., 1976, p. 885; ARNAUD-LINDET, M.P., 2001, p. 261).

${ }^{25}$ Cf. Filóstrato, Vit. Sof., II, 31. En lo relativo al estilo de Eliano, puede consultarse la inteligente síntesis que presenta KINDSTRAND, J.F., 1997, pp. 2985-2988.

${ }^{26}$ Sobre el particular, el lector cuenta con las notas que, entre nosotros, presenta DÍAZREGAÑÓN, J.M., 1984, pp. 11 y ss. En general, la crítica científica tilda —razonablemente-
} 
ción de una cultura vasta y de unas maneras literarias paradójicamente desacordes con la preparación intelectual que atesoraba Eliano, un sobrio estoico por añadidura. Expresándolo de un modo acaso taxativo pero coherente con los resultados de la investigación reciente, la ảkpí $\beta \in \iota \alpha$ científica de Eliano es sensiblemente limitada; y el seguimiento de las fuentes - mediatas e inmediatas - se efectúa merced a cierta inercia acrítica, factor éste de relieve para el problema que nos ocupa.

Mayor interés presenta, para el cometido de nuestra contribución, el panorama de la tradición ecdótica aneja a De natura animalium. No incidiremos sobremanera en la historia de la tranmisión textual, tangencial en buena medida a las cuestiones aquí de interés y examinada con celo modélico por De Stefani. ${ }^{27}$ En lo tocante a las ediciones críticas, la princeps data de 1556 y es mérito de C. Gesner. Esta edición aparecería enriquecida en 1611 merced a la colaboración en la versión latina de P. Gillius, una versión que sería asumida en ediciones posteriores. Más adelante, debemos saludar la contribución de A. Gronovius, de 1744, quien incorpora a la misma - amén de las consideraciones críticas personales - los pormenores de Gesner, en buena medida, y de algunos otros estudiosos cuyas observaciones refiere. ${ }^{28}$ Precisamente en esta edición, comenzamos a detectar el procedimiento crítico que, en el siglo XIX, se vería hipercaracterizado, es decir la actitud permeable a las correcciones - no siempre justificables - del texto en pro de la autoridad de la razón humana, la cual contribuiría, de este modo, a desvelar la opacidad del texto legado y ofuscado por la tradición. Pues bien, tras las aportaciones ecdóticas de J.E.G. Schneider (1784) y C.F.W. Jacobs (1832), asistimos al jalón crítico de significado capital que supone un trabajo de envergadura, la edición de H. Hercher (que su autor completó para la editorial F. Didot en 1858), estudio cuya talla es considerablemente superior a la que patentiza la edición teubneriana de 1864, debida al mismo filólogo. ${ }^{29}$ El caso es que Hercher se muestra generosamente proclive a la intervención crítica del texto, un texto que se pretende viciado de glosas e interpolaciones por doquier. Y, efectivamente, son numerosas las impurezas del texto mas, como recoge Scholfield en la última edición crítica hasta la fecha censada, "it was Hercher's service

de paradoxográfica la obra de Eliano y enfatiza la laxitud literaria que caracteriza al prenestino.

${ }^{27}$ En efecto, el estudioso italiano señala (1902, p. 199) que siete códices "hanno soli il diritto di figurare in un apparato critico della h.a." Éstos son A (s. XIV-XV), F (s. XV), H (s. XIV), L (s. XII), P (s. XIV), V (s. XIII), W (s. XIV). Acto seguido, el crítico se detiene en la consideración de las posibles interpolaciones, omisiones y falsas lecciones que, en su tenor general, testimonian los manuscritos. El resto de los códices documentados constituyen copias de los anteriores (para un 'stemma' persuasivo de la transmisión textual, véase STEFANI, E.L., de, 1902, p. 210).

${ }^{28}$ GRONOVIUS, A., 1744, p. xiii, indica expresamente: "In Animadversionibus ne nimis prolixus forem, sedulo cavi; iisdemque adieci doctissimi Generi Notas, quas in editionem Tigurinam contulerat; nec non Adnotationes posthumas, quas margini eiusdem editionis ab eodem celebri viro adscriptas benevolentiae eruditissimi mihique amicissimi viri, Ioannis Caspari Hagenbuchii, me debere profiteor. His accesserunt notae atque Emendationes clarissimi et utriusque Apollineae artis pertissimi viri, Ioannis Iacobi Trilleri".

${ }^{29}$ Esta circunstancia la recoge y admite SCHOLFIELD, A.F., 1971 (1958), p. vii. 
to have detected the prevalence of glosses and interpolations, although in expelling them he is conscious that some will think that he has exceeded all bounds (Didot ed. Praef. $p$. ii)". Sucede que las ediciones de Hercher, merced al crédito filológico de su autor, obtuvieron fortuna y fueron aceptadas con la aquiescencia generalizada de la comunidad científica, la cual habría de sancionar no sólo sus postulados ecdóticos sino también - y esto resulta obviamente más comprometido- la intelección del texto. Como queda dicho, el curso posterior de las investigaciones ha dado pie a una última edición, merced a Scholfield (1958), que se ajusta por lo común a las propuestas de Hercher. Con todo, se aprecia en Scholfield una labor de eclecticismo y un respeto más escrupuloso al texto que la tradición ha legado.

Efectuadas estas consideraciones globales, veamos cómo afectan las vicisitudes editoriales al fragmento que ahora nos compete para, acto seguido, ofrecer algunas soluciones, las cuales - permítasenos insistirexcluyen de entrada el menor dogmatismo y tienen por cometido el fomento de un debate enriquecedor sobre el problema.

Para empezar con la revisión del fragmento, conviene detenernos en el texto de Gronovius. El pasaje que el autor facilita se ajusta decorosamente a la edición de Gesner y no existe al respecto divergencia alguna. ${ }^{30}$ El caso es que nuestro texto ofrece (en ambas ediciones) un epígra-

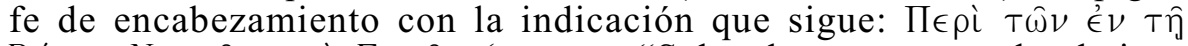

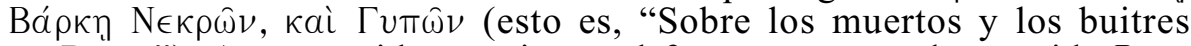
en Barce"). Acto seguido, comienza el fragmento con el conocido Bap-

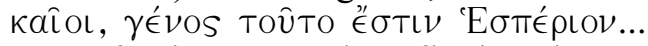

Efectivamente, la reflexión de Gronovius sobre el problema constituye una actitud pionera. El estudioso señala - aunque sin la deseable referencia o explicación al sintagma év Tṇ Вáркn del epígrafe-que se trata de "gens ubique ignota; legendum haud dubie Bakkaîo. Firmatur

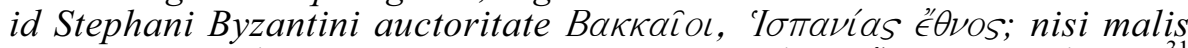

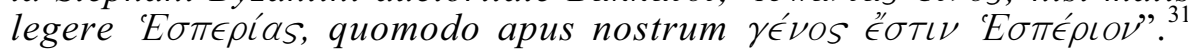
De inmediato, el filólogo trae a colación las apariciones de los vacceos en la historiografía grecolatina. Para finalizar, remite al zoólogo y botánico Samuel Bochart (quien, dada su pericia en el mundo animalístico, estudió la obra de Eliano a fin de corroborar y documentar sus aportaciones personales), como autoridad de la conjetura: "Sed ne quid dissimulem, ita iam legendum in hoc nostro Aeliani loco vidit Bochartus Hierozoic. Part. ii. lib. ii. cap. 27. pag. 318".32 Pues bien, aquí terminan las consideraciones de Gronovius al respecto. Deseamos llamar la atención sobre aspectos determinados: en principio, si se opta por la lección "vacceos", esperaríamos alguna mención incidental a la región de "Barce" que consta en el epígrafe (alusión que parece un resultado de interpretatio crítica a la vista del documentado ßаркаîos). Por otra parte, la men-

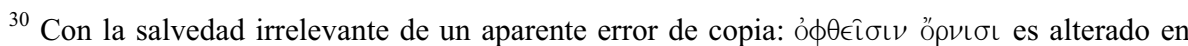

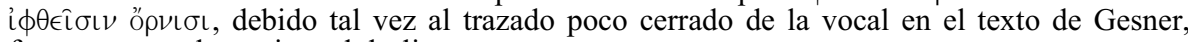
factor que puede motivar el desliz.

${ }^{31}$ GRONOVIUS, A., 1744, p. 1069.

${ }^{32}$ Ibidem.
} 
ción de Esteban de Bizancio (cuya observación sugiere Gronovius alterar para así encajar los datos) carece de cualquier fuerza probatoria. Además, puestos a permutar testimonios, también podría trocarse la forma

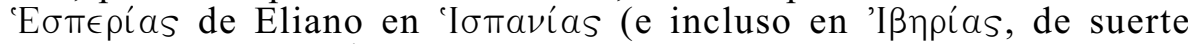

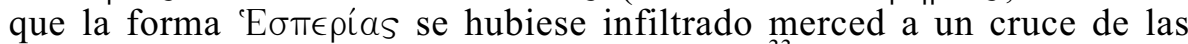
otras dos por vía escrita o tal vez oral-aural). ${ }^{33}$ Por añadidura - como hemos anticipado en nuestra colaboración-, Bochart era un hombre erudito, versado en disciplinas varias, fecundo en viajes y buen observador de la realidad. Sin embargo, no se trataba en sentido estricto de un filólogo, de un historiador o de un etnogeógrafo, por lo que sus apuntes - aun discretos- deben tomarse cum mica salis.

Así las cosas, la edición que Hercher completó en 1858, para la editorial F. Didot, constituye un segundo y capital hito en la historia del texto transmitido sobre la obra de Eliano. Su importancia se vio acrecentada porque el estudio fue acogido unos años más tarde (1864), grosso modo, en la colección teubneriana, lo que la convirtió de suyo en la edición canónica y de referencia obligada prácticamente hasta nuestros días. Ya hemos señalado algunas características de Hercher que se compadecen con el tenor filológico de la época y, a decir verdad, con el optimismo generalizado del hombre ante las ciencias durante el siglo XIX. En consecuencia, no sorprende que Hercher diera pábulo a una inclusión abundante de conjeturas y a la restitución del texto allí donde lo juzgaba insano. En lo tocante a nuestro fragmento, las modificaciones respecto del documento legado son muy considerables. ${ }^{34}$ Como era de esperar, la conjetura Ваккаîol resultó definitivamente admitida y quedó incorporada sin más al relato (algo que todavía no sucedía en la edición de Gronovius, quien proponía la lectura en el aparato crítico). De hecho, Hercher remite estrictamente a Bochart y pasa a demorarse en discusiones críticas sobre otros términos. Ello sancionó de manera determinante una lección que, por inercia ecdótica y de exégesis, ha sido transmitida hasta la actualidad. Y, pese a las aparentes suspicacias de Scholfield en la última edición de 1958, el término Bakкaîo permanece ahí.

Como reflexión de síntesis a las consideraciones establecidas, repárese en que nos las habemos con un fragmento delicado, textualmente complejo, comprometido en su intelección, el cual ha experimentado

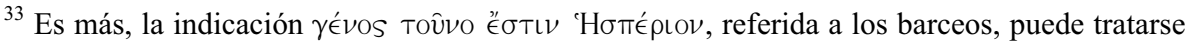
de una glosa añadida en el curso de la tradición. El número de interpolaciones y glosas en la obra de Eliano parece notable. Véase - aunque desde una posición excesivamente radical en sus planteamientos - las observaciones de HERCHER, R., 1858, pp. ii y ss.

${ }^{34}$ Cf. HERCHER, R., 1858, p. xxxvii. Para no ser prolijos, citaremos algunas de las más relevantes, en buena medida injustificadas pero admitidas todavía, paradójicamente, en la edición de Scholfield. Para ello, nos ceñiremos al texto que (con la salvedad consabida de

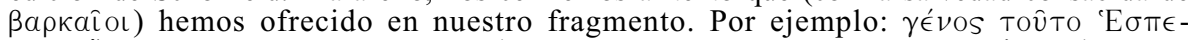

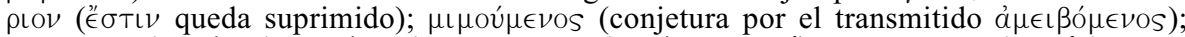

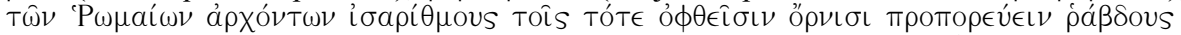

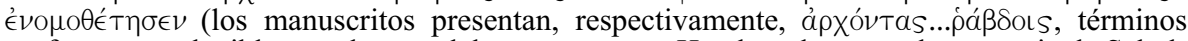
perfectamente legibles en el curso del texto pero que Hercher altera con la anuencia de Schol-

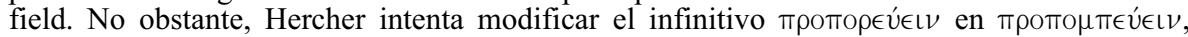
paso que Scholfield declina aceptar). Más justificada resulta la modificación de la forma

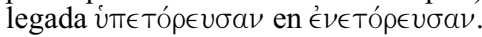


intervenciones críticas muy significativas en número y condición. Por añadidura, resulta probado que la lección sancionada científicamente en la actualidad, ßаккаîo, es ajena a la realidad textual transmitida y cohonesta con extraordinaria dificultad los testimonios históricofilológicos. En tales circunstancias, aceptando que la actitud conjetural se revela precisa para la comprensión de los datos, intentaremos defender la posibilidad de que los hechos hubieran sucedido de otro modo. Como es lógico, no resulta impensable que el término genuinamente transmitido fuera ßаккаîol, que nos enfrentemos a un monstrum léxico y que, por consiguiente, se haga imposible revertir la situación de un modo veraz. Así las cosas, deberíamos admitir la escasa fiabilidad de toda atribución (pero juzgar más verosímil la lectura atenta a la conjugación de los datos histórico-filológicos). No obstante, cabe también la posibilidad de que el desliz se hubiera producido en el curso de la transmisión. Pensamos que una lección como 'A paovakó, por ejemplo, podría hallarse en la génesis del problema. ${ }^{35}$ Se trata en efecto de un pueblo celtibérico, perfectamente distinguido en la tradición historiográfica, cuyos modos rituales y funerarios parecen avenirse con el testimonio documentado. $^{36}$ De este modo, podríamos remontar la deformación terminológica a dos vías de hipótesis:

1. El fragmento mostraría originalmente la formación 'Apaovakoí. Sin embargo, en un momento dado de la transmisión (cuando asistimos al paso de unciales a minúsculas en el siglo IX o en cualquier otra situación de sutileza escriptoria), cierto copista puntilloso y versado en griego habría establecido la síncopa 'Apa/ovakoú. ${ }^{37}$ Este falso corte comportaría principios filológicos de talla, ya que el copista habría intuido el uso inadecuado del morfema paratáctico ópa ("como era de esperar") en posición inicial de cláusula lo que, dado su carácter enclítico, resulta de todo punto aberrante. Acto seguido, una vez reputada espuria la partícula, el paso de *оvakó a *ßakoí (la sinonimia gráfica en el mundo grecorromano ov̉a $=\beta a$ está bien documentada por fricativización del

\footnotetext{
${ }^{35}$ Por ende, no se trataría del único ejemplo que documenta un problema de esta naturaleza. En efecto, el debate entre las lecturas "arévacos" (en su variante y forma de genitivo 'A-

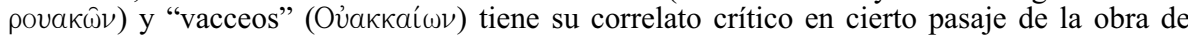
Apiano sobre Iberia (cap. 99, 431). Las formas citadas son respectivas conjeturas de Schweighäuser y Stephanus. Pues bien, resulta de extraordinario interés —absolutamente parangonable a la cuestión que nos ocupa - que la lección facilitada por los manuscritos correspondientes sea también Oủapкаí $\omega \nu$, es decir "barceos". A tal respecto, cf. RICHARDSON, J.S., 2000, pp. 102 (con aparato crítico de enjundia sobre el particular) y 178, donde leemos: "...the manuscripts could be restored to read either 'Arevaci' or 'Vaccaei'“. En atención a los datos historiográficos y filológicos, Richardson se decanta, sin ambages, por leer en el texto de Apiano "arévacos".

${ }^{36}$ Como documenta WALBANK, F., en su monumental comentario a Polibio (1957-1979, ad. loc., XXXV. 2.2, p. 644), el nombre de los arévacos oscila en la tradición historiográfica grecolatina. Están registradas las formaciones: 'Араovakoú (Polibio), 'Арєоvakaí (Tolomeo), 'А роvaкó (Diodoro, Estrabón, Apiano), aravaci (Plinio el Viejo) y aravaci (inscripciones). Para una verificación de los pasajes oportunos, cf. también ADRADOS, F.R. (coord.), 1991, s.v., p. 502.

${ }^{37}$ Debemos a la gentileza del profesor A. Bernabé la orientación de exégesis sobre este problema concreto. No obstante, resulta obvio que todas las posibles insuficiencias de la interpretación son responsabilidad estricta de quienes suscriben la presente publicación.
} 
grupo) y de allí a ßаркаîo (con restitución de la vibrante y regularización del paradigma por analogía a otros gentilicios o etnónimos) se antoja factible.

2. El fragmento evidenciaría asimismo la lección primera 'Apaovaкó́ (о 'Aроvaкó́). El caso es que se habría alterado la copia mediante una duplicación o un trastrueque de letras: así, la lección 'Apaovakoí (leída aravaci) habría pasado a *ßapaovakoí (leída varavaci) y luego

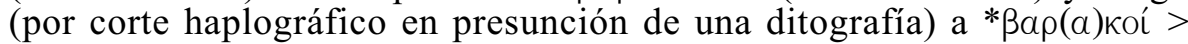
* ßаркои́ > ßаркаî́ol; otra opción se encontraría en la metátesis 'Apaova-

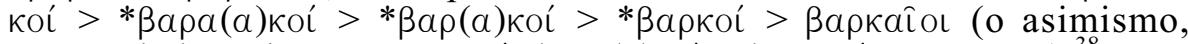

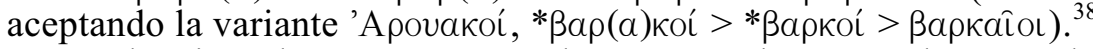

A la vista de cuanto antecede - y con las naturales cautelas que deben presidir toda reflexión procedente de terrenos propicios para el desliz fácil- deberá admitirse la existencia de un problema históricotextual notable, complejo y profundamente atractivo desde disciplinas cuyo maridaje se requiere para un análisis cabal de la realidad de los hechos. Por consiguiente, defendemos como postulados básicos de nuestra interpretación que:

1. La lectura "barceos" (ßаркаîol) que documenta la tradición manuscrita en su totalidad se antoja incomprensible y, en caso de considerarse genuina, mostraría una incuria o inercia palmaria de Eliano en el manejo del dato concreto. ${ }^{39}$

2. La lección "vacceos" ( (аккаîoь) es ajena a la realidad textual que la tradición nos ha legado. Con ello, las reflexiones históricoculturales que se han vertido en la tradición crítica parten, en el mejor de los casos, de una conjetura sancionada ecdóticamente que causó fortuna merced a la autoridad — no siempre filológica- de sus defensores.

3. La presunción del rito que Eliano ha reseñado se compadece atinadamente con algunas prácticas religiosas inferibles, específicamente, en el ámbito arévaco. ${ }^{40}$

4. Considerando la realidad antedicha y la génesis de un problema textual fehaciente, parece claro que hay que optar por una vía exegética que armonice los datos histórico-filológicos. De esta guisa, proponemos dos interpretaciones complementarias, a nuestro entender plausibles:

a) Que la lectura "barceos" (ßаркаîol) fuera genuina, censada por Eliano en seguimiento acrítico de la fuente correspondiente y deturpada acaso por impericia de índole etnogeográfica.

b) Que se tratase de una lección inicial "arévacos" ('Apaovakoí) deformada - mediante las razones y modos esgrimidos anteriormente u otros de tenor análogo- con el paso del tiempo en la lección $\beta a \rho$ кaîoı, la cual habría sido reinterpretada en ßаккаîou por mor de la

\footnotetext{
${ }^{38}$ El excelente manual de BERNABÉ, A., 1992, pp. 26-28, expone atinadamente el cariz de los trastrueques, simplificaciones, haplografías y ditografías en la tipología de errores propios de la transmisión textual.

${ }^{39}$ Salvo que debamos conceder efectivamente la existencia de los "barceos", un pueblo del que no tenemos noticia en la tradición historiográfica y arqueológica de Hispania. Por ello, tal posibilidad se nos antoja poco factible.

${ }^{40} \mathrm{Cf}$. supra, nota 3.
} 
talla crítica y de la envergadura doctrinal que sus impulsores habían concitado secularmente.

\section{EL ESTOICO Y LOS BUITRES: EXÉGESIS DEL FRAGMENTO}

El texto que nos ocupa se halla evidentemente inscrito en una serie de pasajes caracterizada específicamente por la atribución de cualidades sagradas a diversas bestias. Ésta sucesión se inicia en X, 19 y - salvo las interrupciones de X, 25 y X, 30- continúa hasta el final del capítulo (X, 50) y más adelante, en el siguiente. ${ }^{41}$ Verdaderamente se trata de la agrupación de sentido más extensa en esta obra de Eliano, lo que no es en absoluto sorprendente. En efecto, es el arraigado y sincero convencimiento estoico del autor el que guía y aquilata todo el desarrollo de $\Pi \epsilon-$

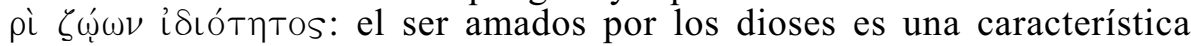
esencial de los animales. La deidad manifiesta su predilección por ellos, sabe cuál es manso y cuál es fiero; y, así, conocer su comportamiento y condiciones es procedente también para el provecho moral de los hombres (XII, 31).

Los estoicos - sobre todo desde el magisterio de Panecio y Posidonio- consideraban que los animales tienen conciencia del propio ser, ergo manifiestan una innata atracción hacia todo lo que preserva y hace prosperar a éste y evita su contrario (o sea, su destrucción): es la oí$\kappa \in i ́ \omega \sigma \iota s .{ }^{42}$ La doctrina atribuye a las bestias un alma definida por la percepción sensible, que en la representación ( $\phi a \nu T a \sigma i ́ a)$ consigue conocimiento: ${ }^{43}$ esta captación interior, mediante el instinto otorgado por la Naturaleza (ópuń) impulsa el comportamiento de los animales. La Naturaleza, entonces, legisla y provee a los diferentes seres vivos de aquello que les es necesario para la vida de una forma inteligente. Esto es: la capacidad del animal para ubicarse en el mundo es, para el Pórtico, siempre cognitiva. ${ }^{44}$

Así pues, aunque las fieras carecen de capacidad discursiva — son

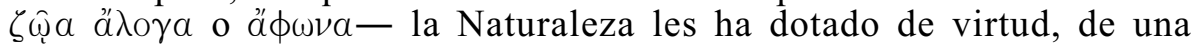

\footnotetext{
${ }^{41}$ La serie prosigue en el capítulo XI, con muy pocas interrupciones en un discurso largo (sólo en los párrafos 12-15, 18, 21-30 35-38 y 40). José Vara, en la introducción a su versión de 1989, anota certeramente - De Stefani lo dejó apenas pespunteado muy tímidamente en su artículo de 1904- cómo una cierta estructuración de los temas puede considerarse característica de Eliano. Así, el autor brinda intencionadamente alternancia de narraciones alusivas a los peces con otras de animales terrestres - o de aves, con intercalación de otras bestias-, repitiéndose este sistema de alternancia varias veces en el texto. Vara afirma que este método es personal del sofista, motivado por su intención particular que tiende a eludir un orden evidente: lo que le agrada a Eliano es la variedad, decir las cosas espontáneamente, tal y como declara en el epílogo de la obra (VARA DONADO, J., 1989, pp. 17-18).

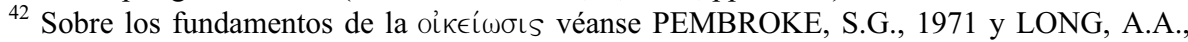
1996, pp. 250-263.

${ }^{43}$ Una valoración adecuada de esta conciencia de sí - tanto humana como animal- en la filosofía del Pórtico puede ser muy bien apreciada en LONG, A.A.,1996, pp. 266-272.

${ }^{44}$ Resultan magníficas las aportaciones de ARANA, J.R., 1999 acerca de la biología estoica. Complementariamente, pueden ser cotejados SHARPLES, R.W., 1996, pp. 68-72 y CLARK, G., 2000. En fin, acerca de Claudio Eliano y su visión de escuela en lo tocante a los animales, MEDINA MÍNGUEZ, L.,1998 y DÍAZ-REGAÑÓN, J.M., 1983 (además de la introducción a su edición de 1984) resultan un complemento sucinto.
} 
intuición adecuada y de una sabiduría innata y dispuesta a su medida

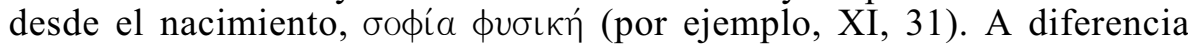
del logos por el que se rige el ser humano - que puede ser inducido a error- esta ooфía natural guía con seguridad a la fauna, siempre de la misma manera y ab origine. ${ }^{45}$ Las divinidades toman en gran consideración esta particularidad; y, así, los animales en la obra de Eliano suelen ser acreditados vehículos de la Justicia o de la divina Providencia. ${ }^{46}$ Los dioses requieren de su colaboración para castigar a los impíos, avisar a los rectos o cumplir cualesquiera otros altos designios. ${ }^{47}$

En estas circunstancias, el autor opera en su De natura animalium como el estoico militante que es: en todo se ajusta el sofista de Preneste al concepto de su escuela acerca de la condición animal, el principio de Razón inmanente y la idea de Providencia actante. La veneración de los hombres hacia los otros seres vivos es perfectamente comprensible, por lo tanto (XIII, 40): se ajusta a unas razones que pueden ser explicadas en tanto que se atienen a la Ley de la Naturaleza. ${ }^{48} \mathrm{Y}$ así procede siempre Claudio Eliano, de tal modo que nos explicará la razón de que sean considerados sagrados animales tan variopintos como la anguila - cara para Aretusa-, el esturión de Panfilia, el halcón de Apolo - al que los egipcios llaman Horo, o sea: Horus-, el Ibis consagrado a Hermes, el raro pez oxyrrinco del Nilo, las mangostas egipcias - consagradas a Letona y a las ilitias, que asisten en los partos-, los perros sicilianos de Ádrano, el pavo real de Zeus, los gallos y las gallinas de Heracles y Hera, los peces sagrados de Hierápolis - muy amados de Astarté- o el pez piloto, preferido de Posidón y los Cabiros de Samotracia. Son ejemplos traídos a vuelapluma: la descripción sería prolija, por supuesto.

El fragmento X, 22 se ocupa concretamente del buitre y resulta peculiar en el conjunto de Sobre la naturaleza de los animales. Ciertamente es muy firme el timón estoico que guía el agrupamiento de los tres motivos aportados por Eliano y el autor, lejos de la orilla del cosmopolitismo de anecdotario, demuestra toda la intención a la hora de escoger qué cuenta y cómo. La calidad sacral del vultúrido viene perfilada en tres vertientes: su potencia augural en el caso romano, su carácter de emblema primigenio de la Madre en la religión isíaca y su condición necrófaga especializada entre los arévacos. Por este mismo orden, y re-

\footnotetext{
${ }^{45}$ La Naturaleza es omnisciente, todo sucede de forma adecuada: lo que deriva de ella es constante (v.g. Séneca, Epist. CXI, 20 y 23. El axioma parte de Posidonio de Apamea).

${ }^{46}$ Por citar un ejemplo, es el caso del aviso del águila de Zeus a Gordio - advirtiendo del futuro regio de su hijo, Midas- o el de la Providencia salvando a Gelón de Siracusa, aún niño, mediante el concurso de un lobo (XIII, 1).

${ }^{47}$ Como el espartano Pantacles, que murió devorado por los perros por su impiedad (XI, 19); o aquel sacrílego que fue aniquilado en Delfos por el ataque de un halcón, enviado por Apolo (II, 43).

${ }^{48}$ La causa natural para explicar el comportamiento animal, en Eliano, es siempre admirable.

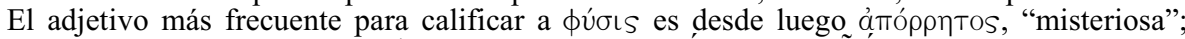

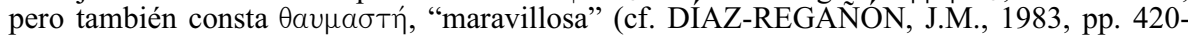
421).

${ }^{49}$ Por orden citado: VIII,4; VIII, 28; X, 14 y XI, 39; X, 29; X, 46; X, 47; XI, 20; XI, 33; XVII, 43; XII, 2; XV, 23.
} 
servando para el final el asunto hispano por razones de estructura, hemos de estudiar con pormenor cada uno de estos aspectos.

\section{1) El augurio de los doce buitres vistos por Rómulo}

El autor demuestra conocer a la perfección el famoso episodio del enfrentamiento de los hermanos Rómulo y Remo, y presenta el asunto sin titubeos: para dirimir la disputa y determinar cuál habrá de ser el emplazamiento exacto donde se ubicará la ciudad que desean fundar, ambos litigantes resuelven - por consejo de Númitor - apelar a los auspicia; y mientras ubicado en la colina Palatina Rómulo observa doce buitres, Remo detecta sólo seis desde su situación en el promontorio del Aventino: irrefutablemente, el destino y los dioses han fallado a favor del primero.

No parece preciso abundar en lo evidente, puesto que Eliano se ciñe absolutamente en todo lo que expone acá a informaciones sabidas, inscribiéndose por tanto en una sólida y robusta tradición de la que dan cuenta fundamentalmente Varrón (Ling. Lat., VII, 7-8), Livio (I, 6,37,3), Dionisio de Halicarnaso (I, 86), Plutarco (Vit. Romul, IX) u Ovidio (Fast., IV, 810-819). Más aún, al precisar el origen legendario del uso de los doce lictores por parte de los emperadores, Eliano se ubica en la misma línea argumental que el propio Cicerón. En efecto, si el de Preneste asegura que las varas simbolizan cada una de las doce regiones del cielo descritas por los buitres augurales, el arpinate afirma: habiendo observado el trazado del vuelo de los buitres - templum in aere- Rómulo delineó con su báculo - conservado en la Curia de los Salios, en el Palatino- las doce regiones del cielo en el momento de fundar la Urbs. Por supuesto, las porciones celestes se proyectaron sobre sus correspondientes terrestres, de donde el símbolo.

Eliano en este caso no se oculta en la anécdota lejana en espacio y/o tiempo. Está aludiendo a un hecho básico de cultura para todo romano, perfectamente conocido y además comprobable por sus lectores - no simple tropa consumidora de novelas milesias, debe insistirse, sino personas capaces de leer en griego. En el conjunto de su discurso no faltan desde luego los animales de los que los dioses se sirven para emitir sus presagios. Así los egipcios utilizan a los cocodrilos, a quienes domestican para sus consultas (VIII, 4), y los peces fagros y meotas son venerados por los sienitas y los de Elefantina: predicen la riada (X, 19). Muchos grandes adivinos griegos pronosticaron a través de las aves, mediante augurio o examen de sus vísceras; y en Licia, se observa el comportamiento de los peces (VIII, 5). También allá, concretamente en Mira, hay unos peces con capacidad agorera consagrados a Apolo (XII, 1). En Lavinia son las serpientes quienes prevén (XI, 16); y los leones egipcios, como amados de Hefesto, inspiran sueños premonitorios y son capaces de echar mal de ojo (XII, 7). La voz del cuervo, en fin, asume carácter sagrado y profético cuando enuncia sus vaticinios (II, 51).

No obstante, en este pasaje que ahora comentamos el augurio de los

\footnotetext{
${ }^{50}$ De diuinatione, I, 17 (acerca de los doce lictores) y I, 107-108 (en lo tocante al augurio, propiamente dicho). Sobre todo ello, consúltese el documentado estudio de LINDERSKI, J., 1986.
} 
buitres se diferencia con claridad de los demás ejemplos del libro. Es la más palmaria ocasión en De natura animalium en la que se particulariza un caso de predicción brindando el resultado del presagio; pero lo fundamental radica en que el motivo traído a colación por el escritor prenestino es de una repercusión enorme: da origen nada menos que a la fundación de la Urbs. El hecho de la grandeza posterior de Roma, capital del mundo a la postre, está certificando la efectividad de las predicciones, la posibilidad cierta de anunciar el futuro y, por supuesto, la omnisciencia de la divina Providencia que privilegió a Rómulo frente a Remo. Es de nuevo el Claudio Eliano profundamente estoico quien se muestra y nos expone aquí, in nuce, la opinión del Pórtico acerca de este asunto.

Los especialistas han señalado cómo las ideas teológicas del estoicismo, alabeadas por influencia de Roma hasta el universalismo cosmopolita, se muestran como un compromiso entre una actitud teórica monoteísta y las representaciones divinas propuestas por las diversas formas de religiosidad del imperio. La acogedora actitud de que da prueba la escuela en relación con la piedad popular, se manifiesta particularmente en la adivinación. Todos sus maestros - excepción hecha de Panecio de Rodas, que permanecía en la duda según informa Cicerón en De diu., I, 3,6 - se afanaron por justificarla desde criterios espirituales y científi$\cos$, tratando de refrenar las tendencias extremas al puro antropocentrismo y al arrebato por lo maravilloso. No sólo de la adivinación se podía obtener argumento en favor de la existencia de los dioses y la Providencia, sino que, más que la claudicación frente a prácticas vulgares, era posible ver en ello un esfuerzo para comprender algo que gozaba del aval de un consensus gentium y, por lo tanto, descansaba sobre una noción común, es decir: natural. Será a través del escolarcado de Posidonio, verdadero puente entre el Pórtico antiguo y el nuevo, cuando adopten cuerpo doctrinal estos esfuerzos por justificar la mántica (Cicerón, De diu., I, 64; I, 129; II, 47). ${ }^{51}$ Como ha destacado Pierre Grimal, el criterio estaba ya perfectamente afirmado en Roma con Séneca, arrimado de nuevo a las tesis de la Stoa antigua. ${ }^{52}$

Todas las cosas en el sistema cósmico se encuentran en estado de conspiración y concordancia. El monismo estoico, como hemos visto, conoce un universo homogéneo en el cual todas sus partes están penetradas y en el que tanto la moral como la lógica reproducen la totalidad orgánica. La adopción de la adivinación como forma válida para las gentes del Pórtico encuentra su apoyo en la estructura de este sistema. ${ }^{53}$ En efecto, la simpatía que ajusta todas las partes del mundo se expresa en las correspondencias de los fenómenos atmosféricos (ciclos lunares, movimientos solares y planetarios, cambios de estación, mareas...). Tales correspondencias no son menos asombrosas que los vínculos posibles entre los presagios y los acontecimientos, desde el momento en que se admite el principio que regula unas y otras: la cooperación que existe

\footnotetext{
${ }^{51}$ ELORDUY, E., 1972, vol. 2, pp. 192-97.

${ }^{52}$ GRIMAL, P., 1986, (sobre todo pp. 145-147). IDEM, 1985, especialmente pp. 35-39.

${ }^{53}$ LONG, A.A., 1987, pp. 111-203 (cf., LONG, A.A. - SEDLEY, D.N., 1987, vol I, revisando la cuestión de la ley de causalidad con más detalle).
} 


\section{Claudio Eliano y el funeral descarnatorio en Celtiberia...}

entre todas las piezas del cosmos. Si la Naturaleza conecta y determina todas las cosas, considerando al universo como un sistema unificado, todo suceso sin causa socava su coherencia. Luego la validez de este nexo causal establece que todos los acontecimientos futuros son teóricamente predecibles. Se trata en suma de la ley de causalidad universal, inmejorablemente planteada por Posidonio según estableció Reinhardt. ${ }^{54}$

En definitiva, aunque con su habitual falta de genio, Claudio Eliano refleja también en este pasaje la posición del estoicismo romano - la suya-, nada reservado acerca de los presagios. El resto del fragmento X, 22 perfila mucho mejor esta expresión del prenestino.

\section{2) El buitre como animal y emblema sagrado entre los egipcios}

Eliano expone seguidamente tres realidades, a saber: el buitre es considerado por los egipcios como animal sagrado de Hera, engalanan con plumas de éste la cabeza de Isis y esculpen relieves de alas de buitre como ornato arquitectónico. Como pretendemos demostrar, también aquí es notable su exactitud pues también es evidente la cercanía de lo que trata.

Desde su origen nilótico, el ciclo de Osiris consagró a Isis como paradigma del amor materno y de la abnegación conyugal, incluso tras la muerte. Se ha señalado cómo la Isis egipcia, en realidad, carecía de distintivos propios, a no ser el Trono. Apareciendo con forma humana y exhibiendo los cuernos vacunos de Hathor, desde el Imperio Nuevo ambas diosas suelen presentarse ya asimiladas, debido a su función maternal preeminente. ${ }^{55}$ Asimismo, resulta natural la fusión de imágenes de vaca y buitre, pues el rey es también hijo del buitre Nejbet, la diosa de

\footnotetext{
${ }^{54}$ Aparte particularidades — que ya se han consignado y que se irán consignado aún cuando proceda-, he aquí las obras generales donde remiten los aspectos que expondremos aquí acerca del estoicismo. ARANA, J.R., 1999, resulta una excelente aproximación al concepto biológico del Pórtico (con especial incidencia en los autores previos al escolarcado de Panecio), al igual que la sobresaliente obra de COLISH, M.L., 1990. Por su parte, ELORDUY, E., 1972, memoria mayor, ya se ha convertido en clásica y de ineludible estudio. La entrega de GARBARINO, G., 1973, es valiosa acerca de la recepción del estoicismo en la Roma republicana, aunque elude aspectos éticos; y GOLDSCHMIDT, V., 1980, es un ensayo muy útil, pero muy basado en el desarrollo del monismo. Sobre la imponente aportación de Posidonio a la escuela sirve todavía KIDD, I.G., 1971; pero es preciso confrontar con IDEM, 1988, II, pp. 430-436 (por supuesto, no sobra revisar los postulados de POHLENZ, M., 1948, vol. I, y REINHARDT, K., 1921, 1954 y muy especialmente 1926). LONG, A.A., es una reconocida autoridad en la materia, por lo que representan referencias muy sólidas sus publicaciones de 1987 y 1996 (y LONG, A.A. - SEDLEY, D.N., 1987). Del mismo modo, PUENTE OJEA, G., 1979 presenta un adecuado enmarque histórico y atinados comentarios de toda índole. RIST, J.M., 1985 implica una buena visión de conjunto; y tampoco defrauda SHARPLES, R.W., 1996, provechosa puesta al día, con especial incidencia en los debates entre el Pórtico, los epicúreos y los escépticos. En fin, VERBEKE, G., 1973 brinda apuntes de precioso interés acerca de la idea del cosmopolitismo estoico.

${ }_{55}$ Ahora bien, Frankfort observó cómo, en relación con el rey, Isis y Hathor conservaron su individualidad. Sólo si el origen del faraón era considerado desde el punto de vista de su divinidad aparecía la imagen de Horus, hijo de la vaca divina Hathor. Si por el contrario se consideraba al rey como sucesor y heredero del linaje regio, su madre era Isis (cuyo significado es el de Trono) y el monarca era el Hijo de Osiris dado a luz por el Trono. Este título de Hijo de Isis - ancestral, puesto que aparece ya en la primera dinastía - certifica la imagen de halcón y toro que del rey se tuvo durante toda la historia egipcia (FRANKFORT, H., 1983, pp. 68 y 195).
} 
Nejeb/Elkab: en cuanto encarnación de la Corona Blanca del Alto Egipto es su madre real y se la exhibe ya en los templos funerarios del Reino Antiguo, criándole tras su renacimiento:

"Tu madre es la Gran Vaca Salvaje, que vivel en Nejeb,/ la Corona Blanca, el Tocado Real /con las dos altas plumas,/ con ambos pechos dispuestos./Ella te amamantará,/No te apartará de su lado". 56

He aquí, en origen, el soporte iconográfico de su corona: los cuernos de Hathor rodeando al disco solar y las plumas de Nejbet (o bien el tocado completo en forma de buitre) ${ }^{57}$ Se ha incidido sobre la significativa etimología de Nejbet ("parto") y sobre la circunstancia de que, en los jeroglíficos, el buitre sea precisamente el signo utilizado para escribir la palabra madre. ${ }^{58}$

Consecuentemente, la vocación universal y polimorfa de la diosa era vigorosa desde antiguo. En El Libro de los Muertos (vigente al menos circa 1633 a.C.) se la nombra como Gran Señora de Vida, la Divina en todos sus nombres, la que cuida de Horus, la Viuda, la Regente, la Gran Barca. Multiplicada, Isis acabó por asumir múltiples funciones: desdoblada (en Neit, Sejmet, Neftis), representada insólitamente (como halcón, concibiendo a Horus sobre el féretro de Osiris, éste en erección), ${ }^{59}$ reinterpretada (Mert Seger, Opet, Selquet, Mut, Tefnut, Maat). ${ }^{60}$ En fin, esta deidad, en su polivalencia absoluta, define bien ese pensa-

${ }^{56}$ Apud FRANKFORT, H., 1983, p. 195. Frankfort explicaba la asimilación de Nejbet e Isis/Hathor como: "Una "concrescencia" auténticamente mitopoética. La idea de la corona y el tocado evoca las dos plumas, que son las insignias más importantes de la Coronación. Además, las plumas concuerdan con el buitre de Nejbet; pero, al ser un par, también hace pensar en los pechos de la diosa que, en forma de mujer, amamanta al rey (...). La misma fusión de imágenes de la vaca y el buitre tiene lugar en otra parte cuando se llama a Nejbet "La Gran Vaca Salvaje... de alas extendidas", e incluso en otro lugar prevalece su forma antropomórfica, si bien está combinada con la de la vaca: "La Gran Vaca Salvaje que está en Nejeb... de largos cabellos" (IDEM, ibidem, pp.195-196). Era usual en el Egipto antiguo que los objetos del ceremonial se convirtieran en personificaciones. Ello explica que, al igual que Isis, - cuyo nombre significa el Trono deificado - "crea" al rey y por lo tanto es su madre, así la Corona del Alto Egipto, Nejbet, "crea" también al faraón y asume la maternidad. Que la Corona a veces no se distingue de la propia diosa Nejbet lo demuestra una colección de himnos que le están dedicados (IDEM, ibidem, pp. 131-132. Cf. IDEM., 1999 (1948), pp. 89-91).

${ }^{57}$ Resultaría interminable la descripción de ocasiones de toda época donde, en lugar de las plumas del ave, lo que aparece explícitamente es la representación de un buitre entero como toca, sobre el que se alzan los cuernos de Hathor, los uraei, el disco solar e incluso el Trono. Son los casos, por destacar dos de especial relevancia, de la famosa tumba de Nefertari, en el Valle de las Reinas, donde aparece así ornada no sólo la diosa, sino la propia reina (MEKHITARIAN, A., 1978, pp. 140-143); o el relieve del templo de Seti I en Abydos, donde el monarca descansa sobre el regazo de Isis, tocada con el buitre, los uraei, el disco solar y los cuernos de Hathor. En tiempos ptolemaicos, es célebre, por citar un ejemplo de belleza admirable, la magnífica representación de Isis como madre de Ptolomeo IV - que aparece sentado sobre sus rodillas en tierna actitud filial - de la sala 24 del templo de Horus en Edfú (SCHULZ, R. - SEIDEL, M. , 1997, respectivamente p. 209, foto 117; y p. 306, foto 31). Véase infra, nota 65.

${ }^{58}$ DERCHAIN, Ph., 1997, p. 410, con bibliografía.

${ }^{59}$ FRANKFORT, H., 1983, lámina 18.

${ }^{60}$ DUNAND, F., 1973b, pp. 87-88. 
miento no disyuntivo típico de Egipto. ${ }^{61}$

Siglos más tarde, la diosa ganará el favor del mundo mediterráneo. Y lo hará con un pasaporte griego en regla, bajo la protección inicial de los monarcas alejandrinos. Fue señalado ya por Cumont cómo el mito de Osiris acabó siendo renovado por éstos, en una política tendente a crear un culto común para helenos y egipcios. Muchas reinas lágidas se hicieron representar como Isis, revalidando la atávica protección divina hacia la monarquía; ${ }^{62}$ y la población helénica del Delta asoció pronto a la madre egipcia con Deméter y los misterios eleusinos, y le dispensó su aceptación. El culto fue llevado por marinos y comerciantes a Grecia, arrastrando consigo al nuevo cortejo osiriaco: Serapis, Harpócrates, Anubis. A partir de su desembarco en Atenas, la diosa demostrará su capacidad de adaptación y se consagrará, paulatinamente, como Gran Madre Universal, asimilada a divinidades de signo cada vez más dispar y ornada con atributos más profusos: Isis, "la de los mil nombres". 63

$\mathrm{Su}$ iconografía incorporará, pues, elementos de discorde orientación. En lo sustancial, a partir del siglo IV a.C. Isis vestirá quitón e himatio - abandonando su larga y entallada túnica indígena- y un manto con faldón que se anudará entre los pechos, destacados para resaltar su feminidad integral. Su discreta peluca egipcia será desplazada por unos largos y ostentosos bucles, que algunos autores han creído de origen libio. Empero, su tocado tenderá a preservar los atributos canónicos de la majestad: la cornamenta de Hathor -ora liriforme, ora insinuando una simple media luna ${ }^{64}$ - rodeando un sol coronado por las dos plumas del buitre Nejbet, estilizadas a menudo, ${ }^{65}$ y el añadido de las dos espigas de

\footnotetext{
${ }^{61} \mathrm{Su}$ capacidad de transustanciación, carácter integrador y profusión formal son básicamente rasgos ya antiguos, no sólo esencia del sincretismo posterior, característica troncal señalada por Frankfort, Wilson, Eberhard Otto y Morenz, entre otros. Hay serias revisiones de la cuestión en ASSMAN, J., 1984; igualmente, cf. BONNET, H., 1971 (1952), pp. 221 y ss., con hincapié en el concepto de Einbegrifflichkeit; y el preámbulo de BALLESTEROS BALBASTRE, F. a la reedición en español del libro de FRANKFORT, H., 1999 (1948).

${ }^{62}$ Será el caso de Cleopatra VII, por ejemplo, que vestía la stola sacra de la diosa y se proclamaba Nea Isis (Plutarco, Vit. Ant., LIV).

${ }^{63}$ Es realmente copiosa la bibliografía sobre Isis en occidente. Constan sólidos planteamientos en CUMONT, F., 1987 (1905), capítulo IV y passim, veteranísimo, de gran lucidez, todavía vigente y fértil vivero de debate; DUNAND, F., 1973a, resulta excelente, con referencias a las categorías funcionales de la divinidad, secuencia temporal e incidencias iconográficas (cf. igualmente, IDEM, 1973b, sucinto, muy útil). El brillante trabajo de TURCAN, R., 1989, capítulo 2 (y passim), es de estudio inexcusable; y MALAISE, M., 1984 (partiendo de su obra de 1972) ofrece un saneado estado de la cuestión, al igual que TAKÁCS, S., 1995. Más recientemente, LECLANT, J., 1997, pp. 373-389, ofrece una panorámica precisa, si bien circunscrita más bien al ámbito fenoménico; MIKALSON, J.D., 1998, brinda en sus pp. 30-31, 37-38, 146, 151-154 y 275-277 un adecuado tratamiento sobre la helenización de Isis, con incidencia en la recepción del culto en Atenas. En español resulta muy conveniente el examen del volumen editado por RUBIO, R., 1996, con participación de destacados especialistas; y es original el planteamiento de BALTRUSAITIS, J., 1996, incidiendo en los aspectos exóticos. En fin, de imprescindible consulta resulta ALVAR, J., 2001, magnífico, con una estructura tan sugestiva como rigurosa y exhaustiva bibliografía.

${ }^{64}$ Heródoto, II, 41; Diodoro, I, 2,4; Plutarco, Is. et Os., 372d.

${ }^{65}$ Sin embargo, como ocurría en la antigüedad egipcia (cf. supra, nota 57), será también frecuentísima en época romana la aparición de la diosa con un buitre explícito como toca (motivo tópico, conocido en la bibliografía francesa con la expresiva definición de "vautour
} 
trigo de Deméter. ${ }^{66}$ Como ha destacado Malaise, aunque las combinaciones sincréticas serán innúmeras, el tocado de Isis - llamado significativamente basileon- será siempre su signo de identidad iconográfica fundamental. ${ }^{67}$

En fin, desde su llegada a Roma, a fines del siglo II a.C., no cesará su asimilación a las más diversas diosas y la adjudicación de epítetos y atributos ${ }^{68}$. En época imperial la devoción se incrementó, sobre todo desde el reinado de Calígula que le consagró el iseo del Campo de Marte; ${ }^{69} \mathrm{y}$, a partir de los últimos antoninos y durante los severos, la veneración culminará en el fervor. ${ }^{70}$

Esta es la Isis de la que nos informa Claudio Eliano, la que él conoció en sus días, la de su momento de máximo apogeo en época severiana: la Isis mistérica, myrionyma, polimorfa, sobreinterpretada. Una Isis, en suma, que gozaba ya de una posición verdaderamente pancósmicaperfectamente establecida en los discursos de Apuleyo, de Plutarco o de las aretologías preservadas-, puesto que la ancestral madre egipcia, de hecho, era la encarnación misma del sincretismo: protectora de la salud, de los niños, del matrimonio y del amor; e igualmente de la fertilidad de los campos, del mundo subterráneo, del destino feliz y de la vida de ultratumba. En estas circunstancias, cuando Claudio Eliano cita a Isis como Hera -asimilación cierta, pero no especialmente habitual- tal hecho no debe interpretarse en este caso como mera simpleza o tosquedad del autor. Bien al contrario, vale decir "la primera de entre todas las diosas", en una actitud estoica que manifiesta apreciar la índole básica de la deidad. Recordemos que en un documento capital para la religión isíaca, como lo es el Primer Himno a Isis del santuario de Madinet Madi (al oeste de El-Fayún), fechable en el siglo I d.C., se equipara a Isis y a Hera. ${ }^{71}$ El carácter último de la diosa queda articulado al final del texto,

accouvé"). Ello resultará harto frecuente en la escultura (cf. un repertorio suficiente como orientación en TRAN TAM TINH, V., LIMC, V, 1, 1990, p. 780; y V, 2, números 255 a-e), pero también en la pintura (VOS, M., de, 1980. Por ejemplo, láminas X, XXIII, XXIV, $\mathrm{XXX} / \mathrm{XXXI})$.

${ }^{66}$ Cf. Apuleyo, Met., II, 4; Ovidio, Met., IX, 688-89.

${ }^{67}$ MALAISE, M., 1976.

68 Los tipos son de extrema diversidad - y a menudo de suma hermosura y espectacularidad- a partir de fines del siglo I d.C. Así, Isis Lactans, con el niño Harpócrates mamando; o, muy frecuentemente, como Fortuna, con el timón y la pródiga cornucopia; o como Afrodita/Venus — acentuando su feminidad — o Deméter/Ceres; o como Isis Thermoutis, con cuerpo de cobra (con Serapis/Agatodemón como paredro); e incluso con los signa panthea, en una abigarradísima expresión de sincretismo. Véase un grupo de ejemplos, agrupado y significativo, en TRAN TAM TINH, V., LIMC, V, 1 (pp. 777 y ss.) y V, 2, 1990, s.v. "Isis"). Resulta inevitable, por cierto, referirse a la vívida descripción de la diosa en plenitud que hace Apuleyo en el siglo II d.C. (Met., XI, 3-4). De otro lado, por mor de la inmediatez, apréciese la diversidad onomástica, por ejemplo, en el clásico catálogo de VIDMAN, L., 1969, passim.

${ }^{69}$ Debe anotarse en este sentido la importante aportación de Germánico, quien contribuyó por su influencia personal a establecer la conexión entre la filosofía estoica y el pensamiento religioso egipcio. Calígula se hizo iniciar en los misterios de Isis en el año 38 d.C. (LE BOEUFFLE, A., 1989, p. 129).

${ }^{70}$ ALVAR, J., 2001, pp. 46-67, 145-154, 216-254 (cf. MALAISE, M., 1984).

71 "Todos los mortales que habitan sobre la infinita tierra, tracios y griegos y bárbaros también, pronuncian tu hermoso nombre, al que honran cada uno en su lengua, cada cual en su 
mediante la helenización $\theta$ coul del egipcio twt: "la única". ${ }^{72}$ Por eso, como ha puesto de manifiesto Françoise Dunand, la elección de Hera es mucho más que significativa, incluso si no se alude a una realidad cultual precisa. En efecto, lo que se establece con esta asignación es la universalidad y superioridad de la madre egipcia, puesto que la simple correspondencia - al viejo uso de Heródoto, por ejemplo- no agota en absoluto el potencial de relación entre Isis y las otras diosas. Hay grados: la asociación analógica es uno de ellos, y esencial además. ${ }^{73}$

Llegados a este punto, parece abonada la idea de que Eliano conoció directamente la cuestión a la que alude sin necesidad de saberes librescos de mayor relieve. Por supuesto que el autor dispuso de obras alusivas a Egipto para la confección de su obra, como dejó perfectamente establecido en su día Wellmann, entre otros ${ }^{74}$ y como lo confirma la exce-

país. Los sirios te llaman Astarté, Artemis, Nanaia; y los pueblos de Lycia, Leto Soberana; y los hombres de la Tracia te dicen Madre de los dioses; los griegos, Hera la del Trono elevado, o bien Afrodita, Hestia la bienhechora, Rhea, Deméter. Pero los egipcios te invocan como $\theta$ lovi, porque eres tú y solamente tú todas esas diosas que los pueblos llaman con otros nombres". DUNAND, F., 1973b, p. 79 Resulta de especial interés confrontar este himno con Apuleyo, Met., XI, 5, a quien citamos en versión de Lisardo Rubio Fernández (1983): “Soy la madre de la inmensa naturaleza, la dueña de todos los elementos, el tronco que da origen a las generaciones, la divinidad suprema, la reina de los mares, la primera entre los habitantes del cielo, la encarnación única de dioses y diosas; (...) soy la divinidad única a quien venera el mundo entero bajo múltiples formas, variados ritos y los más diversos nombres (Apuleyo brinda nueve de ellos); (...) y los egipcios poderosos por su antigua sabiduría me honran con un culto propio y me conocen por mi verdadero nombre: soy la reina Isis".

${ }^{72}$ Cf. VIDMAN, L., 1969, nº502 (=CIL, X, 3800), Una quae es omnia, según reza una inscripción de Capua, del siglo II d.C.

${ }^{73}$ DUNAND, F., 1973b, pp. 80-84. Hera, como es sabido, es hermana y esposa de Zeus y ocupa una posición preeminente en el panteón griego. Gran madre, fue protectora de las casadas y tenía encomendada la regulación matrimonial y la vigilancia de la fidelidad conyugal. Es la virgen y la matrona, pero también la viuda; y las ofrendas a ella ofrecidas en los santuarios demuestran su calidad ctónica - además de la uránica- y su vinculación al mundo marinero (MALAGARDIS, N., JUST, M y SIMON, E. —entre otros - aportan ricas visiones sobre estos aspectos, con bibliografía actual, en el reciente volumen - 1997- dedicado a la personalidad de Hera). Todo ello la acercaba definitivamente al horizonte semántico de Isis, aunque la asimilación no fue demasiado habitual hasta el siglo II d.C. Michel Tardieu ha señalado cómo en los papiros griegos y coptos algunos conjuros identifican a Isis como Hera, esposa y hermana de Zeus ("Isis se fue, llevando sobre sus espaldas a su compañero de cama, su hermano; pero Zeus descendió del Olimpo y se quedó para esperar a los espíritus de los muertos [...]"). Y resulta significativo que se aluda a cómo las plantas son concebidas en el seno de Hera y alumbradas por Isis (TARDIEU, M., 1997, pp. 391-392). En efecto, en esta sistematización final del culto, Isis y Hathor —ésta asimilada desde antiguo a Hera- representan dos matices de la maternidad: la función social (que se inicia en el parto y compete a la educación y la estabilidad de la familia) y la función biológica, extendida desde la concepción al nacimiento (DERCHAIN, Ph., 1997, p. 410).

${ }^{74}$ Según Wellmann, la fuente fundamental de la que toma Eliano sus referencias zoológicas (con seguridad Alejandro de Mindos - también vivero de Plutarco y de Ateneo-, pero a través de Pánfilo el lexicógrafo) empleó las Egipcíacas del gramático Apión de Alejandría. El aserto fue establecido escalonadamente en el tiempo por el citado autor, en varios artículos de apreciable densidad y arrolladora erudición (véase WELLMANN, M, 1891, 1896, 1916); y fue matizado posteriormente por las ricas argumentaciones de RICHMOND, J. (1973: en el origen de las fuentes usadas por los compendios citados se encuentra Aristóteles, quien a su vez fue deudor de otros centones), KINDSTRAND, J.F. (1976: Homero es citado como autoridad por parte de Eliano, pero suele utilizar muy a menudo a sus escoliastas) y STEFANI, E.L., de, (1904: quien observó similitudes exactas entre la disposición del De natura anima- 
lente información de la que el sofista hace gala con relación al país del Nilo; pero lo cierto es que todos los argumentos apuntan a que, en lo esencial, aquél no tuvo necesidad alguna de recurrir demasiado a informaciones ajenas a su propia observación. Sin duda, el escritor prenestino dispuso de todas las oportunidades posibles para comprobar cumplidamente la iconografía egiptizante, tan abundante por aquel entonces en su entorno; y ello incumbe, por supuesto, no sólo al tocado plumado de Isis al que ya hemos aludido hartamente, sino a la decoración alada en relieve. ${ }^{75}$

Lo cierto es que Claudio Eliano se permite aquí un excurso iconográfico único en su De natura animalium. No sólo conoce con toda exactitud los elementos ya citados, sino que quiere detallar aun más, remitiendo a Hathor: los egipcios pintan y esculpen a Isis con cuernos porque existe una relación estrecha entre Afrodita y la vaca, la cual explica (X, 27). También demuestra entender que los áspides bordados en las coronas de los faraones simbolizan otra faceta del poder de su imperio y que es tal culebra quien ciñe las imágenes de Isis Thermoutis, a la que cita

lium y el Epítome de Aristófanes de Bizancio). Por su utilidad al respecto - aunque aludiendo específicamente a Varia Historia - cf. también RUDOLF, F., 1884. Un reciente y excelente resumen acerca de la labor de discernimiento de las fuentes de Claudio Eliano en KINDSTRAND, J.F., 1997, pp. 2971-2977.

${ }^{75}$ Aunque sin duda Eliano corroboró de uisu su apreciación, resulta difícil en este caso concretar más. En efecto, los especialistas en la cuestión inciden en el hecho de que no existen todavía suficientes excavaciones de arquitectura isíaca en la ciudad de Roma y en el conjunto de Italia, con lo que carecemos de los deseables datos específicos (estúdiese el excelente trabajo de PRICE, S., 2000, y véase p. 298). Como simple orientación, parece ocioso reiterar que no sólo la representación del disco solar alado es un motivo nuclear del arte egipcio (FRANKFORT, H., 1983 (1948), cap. 3, esp. pp. 62 y 63 y p. 372, nota 7), sino que la protección simbólica mediante la figuración de divinidades aladas también es comprobable desde antiguo. Muy frecuente es el Horus halcón, pero el buitre gozará de arrolladora y perdurable pujanza. Es Nejbet con las alas desplegadas quien protege, por ejemplo, a Amenenhet III, Amenofis III, Seti I, la reina Nefertari (SCHULZ, R. - SEIDEL, M., 1997, respectivamente: p.116, foto 22 ; p. 190 , foto 80 ; p. 218 , foto 134 ; p. 245 , foto 190 ), o Tutankamón (MEKHITARIAN, A., 1978, p. 118). En Medinet Habu, obra de Rameses III, se combinan todos los motivos alados de índole profiláctica. En la llamada "Puerta Alta" el dintel central exhibe un relieve del disco solar alado y al buitre tocando con sus divinas alas al faraón; y la magnífica "Ventana de las Apariciones" se presenta coronada por un largo friso de cobras, el disco solar alado y, a derecha e izquierda, Nejbet protegiendo con sus alas al rey (SCHULZ, R. - SEIDEL, M., 1997, p. 197, foto 92; p. 395, foto 114). El diseño de estos motivos continuó con todo vigor en época romana, preservando su sentido originario. Así, cabe destacar el templo de Hathor en Dendera, de época de Augusto. Allí, en la fachada de la llamada "Sala de la Capilla Pura", dos dinteles superpuestos sobre columnas hathóricas exhiben sendos discos solares con alas desplegadas y cobras, con evidente sentido profiláctico desde la doble majestad; e igualmente ocurre en la capilla, sobre el tejado occidental — consagrada a Osiris - y en la fachada del pronaos, donde las alas se habilitan sobre seis espléndidas columnas (SCHULZ, R. - SEIDEL, M., 1997, pp. 299 y 300, fotos 11, 13 y 14). También de época augústea, el muro exterior del templo de Opet, en Karnak, exhibe una batería de alas de buitre (LECLANT, J., 1979, III, fig. 50). En fin, el uso perduró largamente; claro y excelente ejemplo de ello viene a ser la Necrópolis de Kom-El Chugafa en Alejandría, fechable en el siglo II d.C.: allí, varias columnas con decoración vegetal sostienen un frontón con las alas del buitre esculpidas (Ibidem, fig.7). Cabe señalar también, en ilustración de este aserto, que en la pared norte del sacrarium del Iseo de Pompeya consta - si bien en una pintura - una representación significativa, agrupando varios emblemas: un babuino - el de Thot-, un carnero signo de Khnum, dios de las cataratas - , un chacal - animal de Anubis - y el alado buitre Nejbet (V.V.A.A., 1992, lám. 1.73 pp. 59-61). 
(VI, 38 y X, 31). En fin, es frecuente que el escritor tome la palabra para aludir a Isis o a Serapis (X, 23; X, 28; XI, 31; XI, 34-35), con pleno dominio de lo que refiere. Su interés, en nuestra opinión, nos remite de nuevo a sus convicciones ideológicas.

En efecto, ya en época de Sila se produjo la asimilación definitiva de Isis a la Fortuna prenestina. ${ }^{76}$ El templo consagrado a Fortuna Primigenia en Preneste fue magníficamente dotado por el dictador tras la reforma de la villa para instalar a sus veteranos, de tal suerte que allí mismo -en sala con ábside - se habilitó el célebre iseo presidido por un mosaico. Autores como Sauron o Malaise - siguiendo a Bayet, Festugière o Harmand - coinciden en señalar la importancia del hecho: se asiste, en efecto, a un cambio efectivo de pensamiento en el que el ciego destino - con aquel recurso a los oráculos típico de la crisis espiritual del siglo II a.C.- queda doblegado a la acción benéfica de la madre egipcia. De tal modo, estamos al inicio del proceso que, finalmente, conducirá a Apuleyo a mostrar a una Isis/Fortuna perfectamente equiparable a la Providencia Universal en el siglo II d.C. (Met., XI, 15), tal y como se la venerará en Preneste. ${ }^{77}$ En todo caso, Eliano, nacido y criado en la ciudad, debió saber del templo y del carácter de la diosa allí venerada, máxime dada su condición de sumo sacerdote pontifical. Más aún, y he aquí la clave: no debe olvidarse que sus fuertes convicciones estoicas le llevaron a la confección de dos obras de título tan sumamente esclarecedor, en este sentido, como Пєрi Прovoías (De Providentia) y

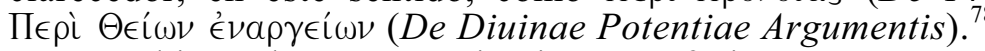

También sabemos que ejerció su profesión en Roma - se jactaba, a decir de su amigo Flavio Filóstrato, de no haber viajado nunca fuera de Italia $^{79}-$, que allí tuvo su casa y que - al igual que Ulpiano, Diógenes Laercio, Galeno, Opiano o el propio Filóstrato, entre otros ilustresperteneció al distinguido grupo de diletantes del pretendido círculo de Julia Domna, la esposa del emperador Septimio Severo. Éste, que, visitó

\footnotetext{
${ }^{76}$ El fenómeno será general en oriente y occidente. En el serapeo de Salónica, por ejemplo, Isis es invocada como Tyché, Tyché Agathé, o Niké; y, en la Delos liberada por el dictador frente a Mitrídates, como Tyché Protogeneia, Tyché Dikaiosyne, Nemesis, transcribiendo en griego los epítetos prenestinos (DUNAND, F., 1973b, p. 82). Resulta verdaderamente notable, por último, la dedicatoria a Isytyché (CIL, XIV, 2867). Cabe señalar que, también en época de Sila, se instaura el culto a Isis Pelagia (o Faria), protectora de la navegación: a ella se le consagra la fiesta del navigium Isis, el 5 de marzo, que marcaría el inicio estas tareas en primavera (por ejemplo, véase LECLANT, J., 1997, p. 375).

${ }^{77}$ El tratado de CHAMPEAUX, J., 1982, sigue siendo referencia clave. Son excelentes los estados de la cuestión de SAURON, G., 1994, pp. 99, 108-111, 131-133, 335 (passim, en lo referido a la dinámica de los movimientos ideológicos en relación con la plástica); MALAISE, M., 1972, pp. 363 y ss; y TURCAN, R., 1989, pp. 87-88. Al respecto de la imagen de la Providencia en el pensamiento romano, su evolución y características propias de la concepción estoica, véase MARTIN, J.P., 1982.

${ }^{78}$ Consúltense los fragmentos preservados en HERCHER, R., 1866, vol. 2, pp. 190-195

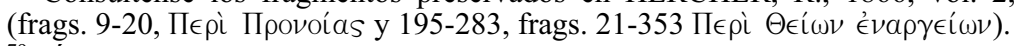

79 Él, que paradójicamente no nos ha legado una sola línea en latín. Resulta divertido dejar constancia de cómo, en pleno frenesí paradoxográfico, Eliano nos garantiza sin embargo (XI, 40) que ha contemplado personalmente...jun buey sagrado de cinco patas en Alejandría! Evidentemente, como anota Wellmann, quien lo "vio" fue su fuente, Apión (es también la opinión de VARA DONADO, J.,1989, p.459, nota 81).
} 
personalmente Egipto, acuñó denarios en los que se muestra a Isis Lactans, con la leyenda Saeculi Felicitas, evocando la próspera maternidad de la emperatriz. Más aún, su hijo Caracalla, desde el 212 y anualmente, detalló en sus monedas su voto particular a Serapis. Hizo un retiro espiritual al Serapeo de Alejandría - donde se tituló Philosarapis-y, en el corazón de Roma, en el mismo Quirinal, consagró un gigantesco templo al dios egipcio - en directa competencia con el de Júpiter Capitolinoal que se accedía desde el Campo de Marte por dos escaleras monumentales: los inmensos fragmentos preservados en la Villa Colonna certifican la magnitud descomunal de la obra. Por otra parte, su sobrino Severo Alejandro enriqueció grandemente el Iseum Campense con estatuas en bronce de Delos y con decoraciones jeroglíficas y nilóticas de toda índo$1 \mathrm{e}^{80}$. En fin, abundantes fueron las capillas públicas y privadas dispuestas en los días de nuestro autor en todos los barrios de la Urbs. ${ }^{81}$

Resulta ingenuo pretender, por tanto, que Claudio Eliano -intelectual romano cultísimo, de impecable formación y exquisitos maestros, ${ }^{82}$ asiduo de amigos cultivados, miembro de un presunto $c l u b$ selecto, cercano a unos príncipes devotos de las divinidades nilóticas- pudiera sustraerse en absoluto a esta poderosa corriente de mentalidad. Por el contrario, su entusiasta militancia en el Pórtico acentuaba su interés sobre el concepto providencial básico que finalmente había adquirido en Roma Isis en sus días: una deidad superior, que constituye unidad con la sustancia eterna, de la que derivan las demás. Y, por cuanto resulta un argumento troncal en este sentido, parece imprescindible concluir reiterando que el autor estoico formaba parte activa del colegio pontifical romano, según lo describe la Suda: su conocimiento de las cosas de los dioses fue una ineludible obligación para él. ${ }^{83}$

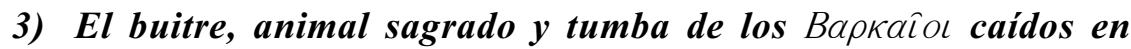 combate}

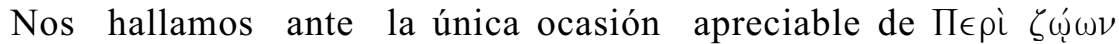

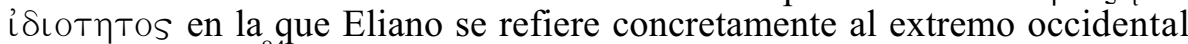
de su ecúmene. ${ }^{84} \mathrm{Y}$ lo hace, significamente, desde un punto de vista etnográfico infrecuente en él: no aborda en este caso cuestión zoológica lato sensu, ni gárrulas anécdotas concatenadas. Lo que describe es exactamente un funeral a través de una autoridad acreditada, a la que en todo

\footnotetext{
${ }^{80}$ LEMBKE, K., 1994, explica con todo rigor y lujo de detalles las particularidades del Iseum Campense.

${ }^{81}$ TAKÁCS, S., 1995, pp. 104-129, con bibliografía (cf. MALAISE, M., 1972, passim).

${ }^{82}$ Apréciese, a fortiori, que — según certifica Flavio Filóstrato (Vit. Sof., II, 31) - Eliano consideraba a Herodes Ático con mayor admiración, si cabe, que a su propio maestro Pausanias: el más sublime de los oradores. Pues bien: como otras ilustres familias atenienses, la de Herodes Ático se había caracterizado por su participación activa en los cultos mistéricos y, entre ellos, de los isíacos (PLÁCIDO, D., 1995, p. 195).

${ }^{83}$ Cf., en este mismo sentido, la opinión de ALVAR, J., 2001, p. 147.

${ }^{84}$ Hay dos ocasiones más, ambas de suma lateralidad tópica y ambas inanes a este tenor: la referencia a los gordos bueyes de Gerión (XII, 11, como glosa a su comentario acerca del toro egipcio llamado Onufis) y al nombre del conejo (denominación que provendría de los nativos de Hesperia).
} 
asume. El autor sin duda ha reparado en un significado ejemplo, que coloca en primer lugar de su descripción de X, $22 .{ }^{85}$

¿Por qué se cita un sepelio tan brusco en una obra que se pretende y se demuestra ligera? Debería aducirse interés exótico antes que gusto de agitador o afán extemporáneo, lógicamente; pero siempre considerando que lo que se está describiendo, en principio, es el más abominable final para la mentalidad común de griegos y romanos desde Homero. Repugnante, inadmisible, desolador, inhumano, terrorífico, la más cruel abyección, un oprobio inconcebible de todo punto: si existe un paradigma de atroz impiedad en la conciencia grecolatina, ese es sin duda la privación de sepultura. ${ }^{86}$ Es decir, toda la intención exótica que Eliano manifesta ahora es la misma que cuando - por única vez también en De natura animalium - habla de los hiperbóreos, remitiéndose a Hecateo de Abdera: se trata de las gentes del máximo septentrión imaginable por un romano (XI, 1). ${ }^{87}$ En fin, el autor nos está ubicando frente a un pueblo muy remoto y de cara a un ritual cuya alta valoración ética, desde el punto de vista estoico, resulta indiscutible en el siempre parco cálamo del sofista prenestino. En efecto, he aquí lo que nos apunta Eliano: la necrofagia del buitre - hecho absolutamente natural - es el uso funeral privilegiado de un pueblo retirado y antiguo por medio del que se habilita el acarreo del alma de los muertos más virtuosos a los cielos. Desde luego, muy pocos conceptos -y todos juntos en un pasaje, además- podían estar más asumidos por un adepto del Pórtico, como procuraremos demostrar.

\footnotetext{
${ }^{85}$ Aunque el autor prenestino suele agasajar a su lector con un copioso festín de datos enciclopédicos, en realidad su aplicación etnográfica es débil respecto a las gentes excéntricas a su gabinete, con las significativas excepciones de la India y Egipto. Fuera del universo mediterráneo y de sus inmediatos contornos, resultan contados los enunciados de calidad considerables como discurso etnológico elianeo. Ha sido éste las más de las veces, por otra parte, sólo establecido para exponer hábitos relativos a la doma, la caza, la pesca, el pastoreo, la monta, la cría, la dieta o el vestido, como corresponde a un libro cuyo protagonismo recae sobre la fauna: Sobre la naturaleza de los animales es una obra sobrepoblada por estos motivos. Desde luego, lo habitual es que a nuestro sofista le interesen más las plagas que obligan a emigrar a algunos pueblos que éstos mismos (XVII, 19; XVII, 40; XVII, 41); o la reina grulla de los pigmeos del alto Nilo que sus súbditos $(\mathrm{XV}, 29)$, a los que sólo cita; o las pieles del alce y del camello más que los caspios y los escitas que las curten, a quienes apenas nombra (II, 16; XVII, 34). A veces, qué duda cabe, aporta informaciones de no poco interés y preciosura: es el caso, por ignotas, de las referidas a Ceilán, (XVI, 17-18); o una propia de los persas, que entrenan a sus caballos arrojando entre sus patas pacas de paja para que no teman los estrépitos, ni pisar los cuerpos humanos en la batalla (XVI, 25); o aquella en la que los gálatas invocan a unas aves - cuya especie omite - mediante rezos y sacrificios - que no detalla - para ahuyentar a las langostas (XVII, 19); o aquella otra, en fin, en la que describe cómo los psilos de Libia no sólo son inmunes al mordisco de las alimañas, sino que su propio organismo genera el antídoto contra ellas (XVI, 27-28). No obstante, su obra está francamente ayuna de verdaderas y detalladas descripciones rituales (cf. apenas IV, 2 y X, 50, si bien no alude aquí a pueblos periféricos, sino a una fiesta celebrada en Erice de Sicilia; o XVI, 16, donde se refiere a la Sima de Plutón, en la India, apta para la conjuración de los augurios y presagios desfavorables).

${ }^{86}$ Por citar alguna bibliografía sobre cuestión tan recurrente en los estudios, resultan excelentes, por ejemplo, VERNANT, J.P., 1982 y VERMEULE, E., 1984, en lo referido a Grecia; y LAVAGNE, H., 1987 y DUCOS, M, 1995 en lo tocante a Roma (cf. BALSDON, J.P.V.D., 1979, pp. 252-257; y SOPEÑA, G., 1995, capítulo III y passim ).

${ }^{87}$ Un tratamiento certero del problema, en el conjunto de la percepción etnocéntrica romana y de la idealización de lo lejano, se destaca en MARCO SIMÓN, F., 2000.
} 
Claudio Eliano compone su obra en un momento en el que Roma manifestaba ya un serio interés por la conciencia moral y el destino del individuo tras la muerte. Es un asunto de sobra conocido y destacado por los mejores tratadistas sobre religión romana: tal preocupación afectó tanto a los espíritus cultivados cuanto al común de las gentes, tiempo como fue de incertidumbres en lo personal, de exuberante intelectualismo "barroco" y de éxito de los cultos orientales. El eclecticismo, inevitablemente, hizo mella en los postulados estoicos. Desde el escolarcado de Panecio y hasta Marco Aurelio, la Stoa romana no dejó de asimilar numerosas tendencias platónicas y aristotélicas, mostrándose especialmente permeable a partir del siglo I d. C., incluso a los criterios de los cínicos. Las cuestiones escatológicas, lógicamente, fueron proclives a estos influjos. ${ }^{88}$

Uno de los rasgos más notables del pensamiento estoico es su clara orientación biológica, como ya se ha visto. Desde Crisipo, la teodicea de la escuela postulaba la existencia de un principio activo del universo, un elemento inteligente, ubicuo, único e idéntico a Dios, que se despliega y origina todos los elementos. El Espíritu del Mundo, razonable, vital, artista consumado: es el pneuma, aliento ígneo y aéreo, vehículo de la Razón de la Naturaleza que todo lo conecta.

Considerando la Stoa que todo lo existente es corpóreo, las cualidades morales son cuerpos que constan de materia y pneuma. El ser humano, así, es una sustancia única, pero distintas son su hechura física y sus facultades. Ciertamente, todos los atributos del hombre son debidos a la penetración de la materia por el pneuma. El alma, pues, es una porción de este aliento divino que atraviesa el cosmos todo; y lo que permite tal permeabilidad en el hombre es el cuerpo, donde éste responde a la materia.

Frente a las actitudes más racionalistas de su escuela, ${ }^{90}$ Posidonio brindó la reflexión determinante en la definición del perfil teosófico del estoicismo romano posterior a él. Partiendo de los axiomas anteriores, el maestro sirio sostuvo (en elaboración evidentemente tintada por las tradiciones órfico-pitagóricas y platónicas ${ }^{91}$ que el alma, tras la muerte, se instala al separarse del cuerpo en la atmósfera. El pneuma individual es el daímon personal que, dejando atrás la materia, asciende a los espacios aéreos hasta alcanzar la densidad pneumática correspondiente a la pureza espiritual de ese daímon. Estas ánimas puras volarán a los más altos lugares siderales para gozar de una vida eterna, sin límites, en plenitud hasta la conflagración definitiva que pondrá fin a las cosas y se reitegrará con Dios. ${ }^{92}$ Por el contrario, la maldad perturba el pneuma y eleva tanto su densidad que, lastrada sin remisión, el alma es incapaz de aban-

\footnotetext{
${ }^{88}$ PUENTE OJEA, G., 1979, pp. 146-148. Igualmente, véase LONG, A.A., 1984, pp. 220 y ss.

${ }^{89}$ La obra de VERBEKE, G., 1945, resulta muy ilustrativa acerca del concepto estoico del pneuma (sobre el sistema de categorías y la cualidad corpórea/incorpórea, material/inmaterial, también ha incidido bien ELORDUY, E., 1972 vol. I, pp. 242-263).

90 Alguna de las cuales, como la de Panecio, llegó a negar la presunción de la inmortalidad individual.

${ }^{91}$ SAMELLAS, A., 2002, pp. 45 y ss.

${ }^{92}$ Es útil comparar con Cicerón, De nat. deor., II, 118.
} 
donar las capas bajas de la atmósfera; y allí permanecerá, coexistiendo en apagada vecindad con otros seres de la misma laya. ${ }^{93}$

La más frecuente y casi única aportación de Claudio Eliano es elegir lo que transmite. Y lo que relata aquí es, explícitamente, la evidencia de un movimiento del alma hacia los cielos por medio de un animal volador, psicopompo, de índole sagrada. El robusto estoicismo del sofista comprendía perfectamente la intención de la observación de su informador - que aparenta ser el mismo Posidonio, directamente o a través de intermediarios- y reconocía su doctrina en ella. Pero más aún y muy en concreto: el de Preneste alude a la sola selección de los mejores, por el noble ejercicio de la virtud. Inobjetablemente, uno de los mayores dogmas estoicos es la igualdad de todos los hombres, llamados por la Naturaleza a idéntico cultivo de la areté según sus circunstancias.

Se indicaba más arriba cómo la conformidad con la Naturaleza es la fuente de toda virtud. Aquélla sanciona las normas para todos los seres -ora animales, ora hombres-, por referencia a las que cabe decir que alcanzan o no sus fines individuales. La pertinencia en las acciones radi-

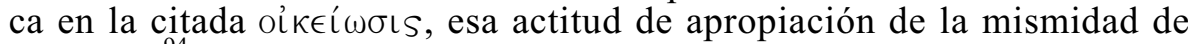
cada uno. ${ }^{94}$ Siendo el hombre el único ser capacitado para comprender y promover la racionalidad natural con su esfuerzo, puede obrar en desacuerdo con ésta: es un agente moral pertrechado de vocación hacia la virtud, pero frágil frente a las influencias externas que pueden impedirle la relación armónica con la Naturaleza. El Pórtico romano sólo considera al hombre en concreto, formado por las disposiciones individuales propias, las circunstancias externas de la vida y su pertenencia a una colectividad. La Providencia no fija el destino: lo edifica la personalidad pro-

\footnotetext{
${ }^{93}$ El estudio de HAHM, D.E., 1977 (cf. pp. 111-114) sigue resultando orientativo. Igualmente, LONG, A.A., 1996, pp. 224-249. La dirección espiritual de Posidonio brindaba categorías que, en los siglos siguientes a él, se extenderán por todo el Imperio, abonando un fértil sustrato para el triunfo definitivo de las poderosas ideas cristianas. Franz Cumont demostró en su día cómo, a partir del siglo II d.C., el repertorio iconográfico sepulcral se convirtió en una repetición de composiciones estereotipadas con intención religiosa. La plasmación icónica de antiguas fábulas helénicas y latinas acabó siendo simple ilustración simbólica de las creencias cósmicas extendidas por el estoicismo y el neopitagorismo en auge. Roma, en efecto, había asumido absolutamente la creencia en la naturaleza aérea de las almas, que podían quedar sometidas al soplo de los vientos. La doctrina pitagórica, asimilada por el estoicismo, destacó la inmortalidad aérea de las almas que, en su ascenso, se dirigen al reino de los astros (véanse los estudios de CUMONT, 1949 y 1966. Igualmente, es útil LE BOEUFFLE, A., 1989, pp. 113-135 y, especialmente, pp. 122-125. Cf. SOPEÑA, G., 1995, pp. 240 y ss.). Es imprescindible la consulta del edificante análisis de SAMELLAS, A., 2002, passim.

${ }^{94}$ Empero, obrar de acuerdo a la Naturaleza es una cosa, otra es la calificación moral. La elección de algo conforme a la Razón universal en el hombre queda sólo a mitad de camino en la adquisición del conocimiento, aunque es una condición necesaria de la acción virtuosa. Para la intelectualidad estoica el fin esencial era el perfeccionamiento interior, capaz de permitir la práctica de las grandes virtudes: el ideal del sabio. La apoteosis personal, sin embargo, no podía ser más que una excepción ofrecida a las almas capaces de realizaciones lejos del común. El hombre divino será el gran estadista, el filósofo; pero muy significadamente el emperador. La posesión de cualidades y de voluntad sobresalientes para ejercer la virtud resultaron condición indispensable para esta clase de divinidad. Véase un brillante desarrollo de la cuestión en ARCE, J., 1988, capítulo I y passim. Igualmente, consúltese LE BOEUFFLE, A., 1989, pp. 125-129.
} 
pia con su desarrollo. ${ }^{95}$

Pues bien, a través de su fuente, Eliano ejemplifica con el presente fragmento esta teoría estoica de la virtud. Ciertamente, la Razón universal ha provisto al buitre de la capacidad que le es precisa para la vida: la

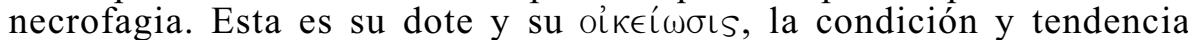
específica del ave, como el sofista ha dejado establecido también en II, 46. En este sentido, el vultúrido actúa de conformidad absoluta con la norma de la Naturaleza: cumple en todo el fin que le es propio y para el que ha sido diseñado. Ahora bien, nótese que son los arévacos (según nosotros interpretamos Bapкaîo ) quienes le entregan voluntariamente los cadáveres de los que ellos consideran sus mejores varones, con lo cual no hay nada accidental en este sepelio: se condiciona el comportamiento propio del ave - a la que, además, le atribuyen calidad sagra$\mathrm{da}^{96}$ - , ajustándolo deliberadamente a la racionalidad natural. Estos hispanos son, por tanto, estrictamente virtuosos.

Lo son, puesto que para ellos lo propio de un verdadero uir es caer en el combate: esa es la naturaleza de su uirtus; pero lo son también por su desprecio a la muerte, reconocido por Claudio Eliano y su fuente. En efecto, como la lógica es el camino de la verdad, así la ética es el camino de la virtud para el estoicismo: el desdén frente al morir compone el ideal más alto y heroico de todo hombre. Sólidamente trabado en el sistema filosófico del Pórtico, los motivos de tal desprecio radican en la tesis de que la muerte es algo indiferente con apariencia de mal. El alma y el cuerpo se disocian en el deceso, dejando el hombre de ser lo que fue; pero no por eso se perece: se trata, como explica emocionantemente Séneca, de un retornar del ser a la Naturaleza (Ep., 71, 14). La muerte, en fin, destruye o alivia; y a los que despide sin la carga que traían, les aguarda un estado de paz perpetua (Ad Marciam, VI, 19, 6): a quienes son aniquilados no les queda nada, ni bueno ni malo (Ep., 24, 18; 65, 24). ${ }^{97}$ Eliano, indisputablemente, compartía esta visión con un convencimiento pleno. ${ }^{98}$

\footnotetext{
${ }^{95}$ Desde el escolarcado de Panecio (véase GARBARINO, G., 1973, vol. 1, pp. 27-36), pero muy especialmente tras el magisterio de Posidonio, como ha demostrado KIDD, I.G., 1989, pp. 46 y ss.

${ }^{96}$ Eliano adviertirá con posterioridad de que las aves rapaces en su conjunto están vinculadas a dioses, y concretamente el buitre es animal de Atenea (XII, 4).

${ }^{97}$ El propio Séneca explica las cuatro causas del miedo a la muerte: la repugnancia natural a reintegrarse a la Naturaleza, por la idea de disolución; el desconocimiento de lo que hay más allá de esta vida; la creencia de que la muerte está llena de tinieblas; y la impresión que causan los suplicios infernales que describen los poetas (Séneca, Ep., 82, 15-16). En última instancia, primará la reintegración final con Dios (cf. Epicteto, III, 24 y Marco Aurelio, IV, 14). No procede abundar en la especial importancia y extensión de la parenética estoica. Los diálogos de Séneca y la obra de Marco Aurelio son ejemplos destacados, pero también los tratados de Musonio, Epicteto, o Antípatro, además por supuesto de los Stoicorum ueterum fragmenta (sobre todos estos aspectos, sigue resultando de suma utilidad la aproximación de HOVEN, R., 1971; y, en concreto sobre la Stoa nueva, ELORDUY, E., 1972, vol. 2, pp. 150-163).

${ }^{98} \mathrm{Su}$ declaración en $\mathrm{V}, 34$, resulta diáfana. Los hombres, dice, tenemos miedo de lo que desconocemos y creemos ver en la muerte el peor de los males; pero, a diferencia nuestra, el cisne sobrelleva la idea de la cesación con tal ánimo que, llegada la hora, entona una canción
} 


\section{Claudio Eliano y el funeral descarnatorio en Celtiberia...}

Nuestro autor, en definitiva, a través de la autoridad a la que asume, no nos ha colocado en el extremo occidental de su ecúmene gratuitamente. El carácter tremendo del rito al que él alude queda decididamente contrapesado intelectual y éticamente con el dogma del Pórtico acerca de la uirtus y permite a Eliano traer a colación tan bronco funeral sin trauma y de modo pertinente para sus cultivados lectores: nada más familiar para un estoico, en efecto, que la existencia de un severo sistema moral entre los primitivos que privilegie la bella muerte con la aplicación de un sepelio sencillo y en todo ajustado a la Razón Universal. La administración divina del universo es visible también en la reintegración en la Naturaleza tras el deceso: evidentemente la Providencia es la distribuidora de premios y castigos, la propiedad de la virtud es la consecuencia lógica de la Naturaleza.

Ello es lo fundamental y no el talante de las honras fúnebres. Desde luego, queda fuera de cualquier controversia que el Pórtico ejercía las prácticas pías de sepultura; ${ }^{100}$ sin embargo, el horizonte ideológico de una despreocupación por los aspectos exteriores de los sepelios -estrictamente intelectual, por supuesto- resulta un vector director de la escuela, al menos desde el siglo I d.C. ${ }^{101}$ Tal indiferencia es tan significada que implica, de hecho, un acercamiento a las posturas de los cínicos, en el sentido de Naturalia non sunt turpia, como ha destacado Long, entre otros. ${ }^{102}$ Así, esta actitud sería visible anecdóticamente en Diógenes Laercio, quien le atribuye a su homónimo cínico de Sinope un perfecto desdén por lo que se haga con su cadáver: bien sea abandonado o entregado a las aves o a los perros, para que en algo aproveche (Diog., VI, 79); pero podrá ser inmejorablemente rastreada en la argumentación pagana expuesta explícitamente por Minucio Félix, en boca de su perso-

última, a modo de homenaje para sí. La Naturaleza le ha provisto del más hermoso don: tener el convencimiento de que no hay nada de triste ni de doloroso en este último trance.

${ }^{99}$ Por ejemplo, véase ELORDUY, E., 1972, I, p. 280.

${ }^{100}$ Como se sabe, la cremación primó en la zona occidental del Imperio, mientras en la oriental predominó la inhumación, que a mitad del II d.C. se impuso (resultan clásicos NOCK, A.D., 1932 y TOYNBEE, J.M.C., 1971; pero conviene consultar además MORRIS, I., 1992, pp. 31-69; DAVIES, J., 1999, pp. 139-154; y PATTERSON, J.R., 2000, pp. 264 y ss.).

${ }^{101}$ La cuestión es sumamente compleja, por lo que apenas esbozaremos aquí algunos rasgos, en espera de profundizar sobre ello quizá en ocasión futura. Antigone Samellas, en su soberbio estudio, señala elocuentemente cómo:"'The new physicians of the soul shared with the ancient school of medicine the belief that philosophy was a discipline, a method through wich the rational will could be instructed what to desire and what to avoid, an art of living wich cured its conscientious practitioners from all troublesome emotions. They too included among the limitless possibilities of Reason, the indoctrination of the mind with rational arguments, the development of techniques of vigilance, such as the internal monologue and the withdrawal of assent from false impressions, the habituation of the imagination to representations of death and the building-up of psychological defences. At the same time, however, they added new priorities to the preparation of the commanding faculty for the incidence of death by making the body, something wich the Stoics classified among the "indifferents", the privileged arena of Reason's fight with the irrational" (SAMELLAS, A., 2002, p. 104). No debe abandonarse la muy ilustrativa la consulta del capítulo titulado "Soul and Body in Stoicism" en el compendio de LONG, A.A., 1996, pp. 224-249; y cf., complementariamente, lo aportado por KYLE, D.G., 2001, capítulo 5.

${ }^{102}$ LONG, A.A., 1987, pp. 111 y ss. 
naje Caecilius Natalis: los cristianos maldicen ridículamente la cremación, puesto que da lo mismo que los cuerpos sean devorados por las fieras, o tragados por el mar, o enterrados, o quemados: la carne será convertida en nada finalmente por el tiempo; y si los cadáveres tuvieren sensibilidad, cualquier sepultura sería ya un castigo de por sí, y, si no la poseyeren, lo mejor es que la descomposición sea lo más rápida posible (Oct., XI). Para el Pórtico, en fin, según establecía ya Epicteto, el cuerpo efectivamente debe considerarse como algo indiferente (Encheiridion, I); y precisamente, disponemos de un valiosísimo pasaje etnográfico de Silio Itálico (Pun., XIII, 466-487), donde cita, como tópico, el rito de exposición hispano perfectamente integrado junto a las prácticas de hircanios, egipcios, habitantes del Ponto, garamantes, nasamones, celtas, atenienses y escitas: todas ellas absolutamente atestiguadas por otras fuentes. ${ }^{103}$ Pues bien, Spaltenstein anota con inteligencia cómo nos encontramos ante un excurso claramente alusivo a este ideal de la Stoa: entereza frente a la muerte, relativización de la importancia y estilo de las exequias. ${ }^{104}$

El estoicismo considera que la virtud es adquirible, pero también amisible por las muchas celadas que le tiende la vida en el mundo. Los hombres primitivos - aquellos más cercanos al origen, a la Ley Natural一, más puros de todo vicio, están dotados de excelente aptitud para la adquisición de una virtud perfecta. No se entregan a comodidades que les son desconocidas, y por tanto no las echan de menos en la hosca rudeza de su idiosincrasia. El propio Séneca observa todavía rasgos atávicos de ese vigor innato y primigenio en los tipos exóticos, ajenos al refinamiento de la Urbs; y lo hace invocando a una de las voces más acreditadas de su escuela: Posidonio (Ep. 90, 7).

En efecto, creemos presentable que sea Posidonio la fuente última seguida por Eliano. Como se sabe, el erudito sirio visitó en persona Hispania, Galia y parte de la región alpina, así como las Islas Británicas, en torno al año 100 a.E; y su obra continúa la narración polibiana desde los años 145 al 82 a.E. Los especialistas apuntan jústamente cómo la obra histórica y geográfica de Posidonio constituye, de hecho, una condensación de la tradición mediterránea en la experiencia con los bárbaros que, a partir del polímata, no hará sino diversificarse según las intenciones concretas de los autores que le siguieron. Posidonio no sólo resulta piedra angular de la física, la lógica y la ética de su escuela: su peso específico resulta absolutamente determinante como base fundamental de la etnografía posterior. ${ }^{105}$

\footnotetext{
${ }^{103}$ Véase SOPEÑA, G., 1995, pp. 217-218, con comentarios críticos, traducción, bibliografía y exégesis.

${ }^{104}$ SPALTENSTEIN, F., 1990, vol II, frag. 13, 468, pp. 242-243.

${ }^{105}$ Sobre ello ha incidido exhaustivamente, TIERNEY, J.J., 1960, pp. 199, 211, 223 y passim. No es quizá este el lugar más adecuado para extenderse con este asunto, pero es preciso apuntar cómo el de Apamea es un jalón capital en la acomodación del Pórtico a la vocación hegemónica de la Urbs. Desde su magisterio, el estoicismo compondrá el mejor cimiento conceptual de Roma sobre su ecúmene unificada: una superestructura ideológica que aprecia los postulados de la filantropía y un orden universal basado en la Ley Natural. Posidonio, según explicó Reinhardt, creía en una armonía providencial que unía cielos y tierra y convertía el
} 
Posidonio manifestó un sincero interés por el modo de vida de los bárbaros, pudiendo reconocer un apunte fiel de la doctrina del Pórtico entre ellos. Malitz y Kidd, junto a Laffranque, anotan cómo el sabio griego vio a estos pueblos como un modelo del hombre cercano a la armonía natural y, por tanto, tendente al estoicismo: virtuoso, ingenuo, con un modo de vida moderado, no corrupto por la riqueza y regido por antiguos ideales heroicos. ${ }^{106}$

De sobra han insistido estudiosos y editores en que Eliano manejó sobre todo centones: recopilaciones tardías, por lo general, elaboradas a base de textos intermedios cuya intención era tan sólo la acumulación de datos famosos. Empero, que el sofista conocía y asumía la obra de su escolarca Posidonio es un hecho que no admite duda: otra cosa es discernir si empleó su narración etnográfica ad hoc (cosa que no repugnaría al buen sentido, pero que constituye mera presunción cabal); y, al margen de que también se consigne como fuente del prenestino a algún discípulo directo del de Apamea, ${ }^{107}$ resulta básico cotejar la información de Eliano al respecto de tan especialísimo sepelio con lo que nos ha legado, al mismo tenor y previamente, Silio Itálico. Dice éste:

\begin{abstract}
"Llegaron también los celtas, asociados en nombre a los iberos. Prez supone para ellos el haber caído en la lucha, pero quemar un cuerpo asi no es lícito. Al cielo y a los dioses creen ser conducidos si un buitre hambriento desgarra sus miembros yacentes". (Pun., III, 340-343).
\end{abstract}

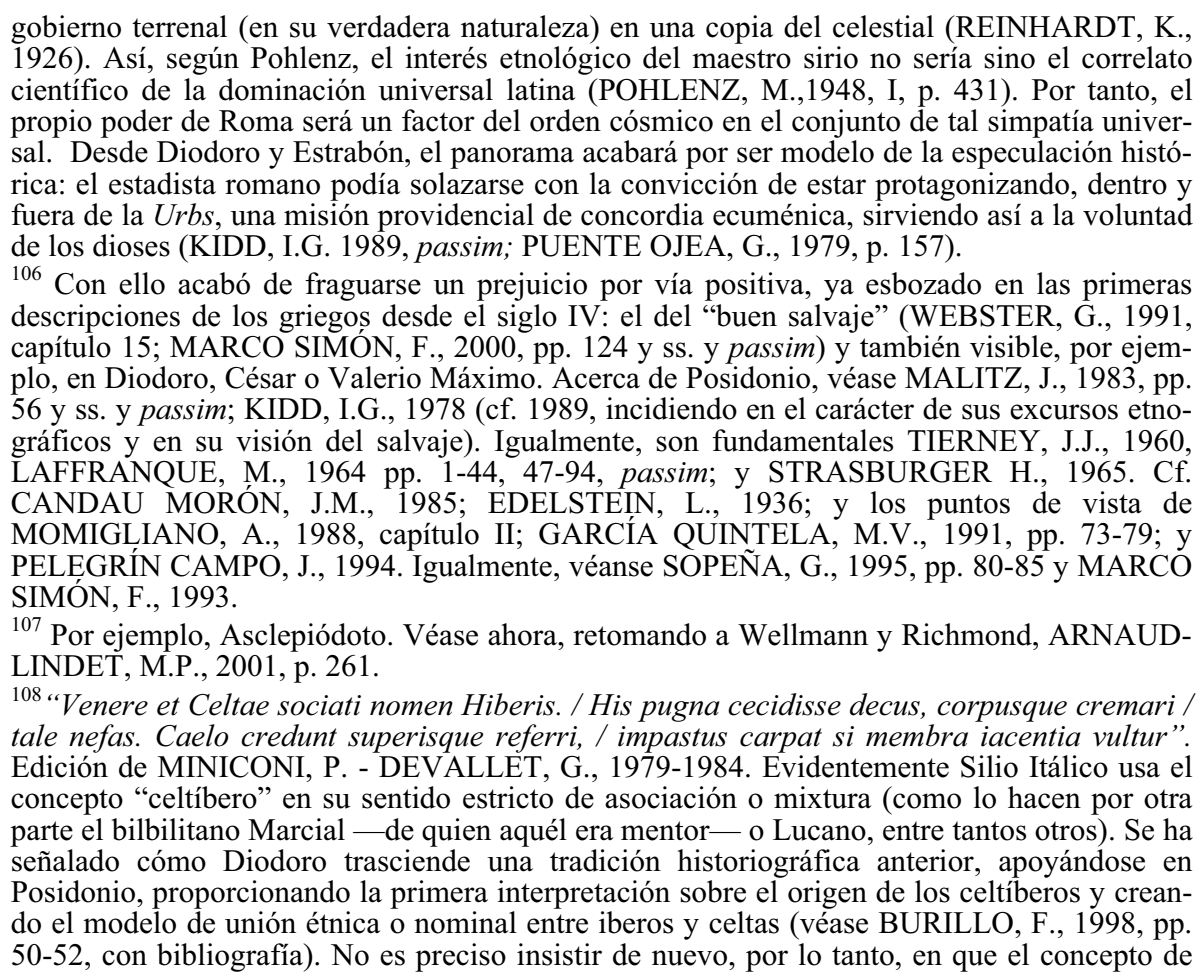




\section{Gabriel Sopeña - Vicente Ramón}

La inspiración e intención de Silio Itálico fueron estrictamente literarias; ${ }^{109}$ sin embargo, los expertos insisten en cómo su información etnográfica consta normalmente como inmune a las deformaciones. Silio Itálico - varón rico, de absoluta probidad, cultísimo, con excelentes relaciones personales y estoico que puso fin voluntariamente a su vida ante la certidumbre de un mal incurable- se aplicó entusiasmadamente a la erudición en su vejez: sus fuentes son, en verdad, magníficas. ${ }^{110}$ En fin, para lo que aquí interesa, en lo tocante al lapso entre los versos 222405, la autoridad de Nicol pudo desglosar a Heródoto, Timeo y, significadamente, a Posidonio. De hecho, Silio Itálico parece haber seguido la tradición analística de Polibio sólo a través del de Apamea. ${ }^{11}$

Apréciese cómo el contenido de las citas de Silio y la de Claudio Eliano es idéntico, con un matiz: practicada por estos hispanos - celtíberos en conjunto para el vate, arévacos (según nuestra interpretación de Bapкaîol) en concreto para el sofista- se establece una neta discriminación funeral entre los más virtuosos y el resto, sobre la base de la creencia en el transporte del alma al más allá, vía aérea, mediante la necrofagía del vultúrido. ${ }^{112}$ Ambos hablan ex euentu, ambos deben remitirse al mismo origen, acaso Posidonio: Claudio Eliano detallaría al pueblo celtibérico más significado para Roma, consignando directamente el dato transmitido, pero deturpado. ${ }^{113}$ Silio Itálico, resignado en el metro poético y elaborando con afán épico, alude a la generalidad celtibérica por mor de la simple evocación; y por la misma razón extiende luego a toda Hispania, como tópico, el rito propio de los celtíberos. ${ }^{114}$

mezcla como sustancia total del universo y como elemento de explicación ontológica es uno de los postulados esenciales del estoicismo: un auténtico saber de escuela.

${ }^{109}$ Véase SOPEÑA, G., 1995, 1995, p. 218, nota 43, con bibliografía.

${ }^{110}$ BARDON, H., 1972, pp. 739, 782 y ss. y passim ; CUPAIOLO, F., 1973, pp. 127 y ss.

${ }^{111}$ Estúdiese en detalle, NICOL, J., 1936, pp. 25, 47-49, 130-131, 151-155 y 157-166. Cf., más recientemente, SPALTENSTEIN, F., 1990, vol. I. frags. III, 340-343.

${ }^{112}$ Una argumentación in extenso puede verse en SOPEÑA, G., 1995, passim (especialmente, capítulo III).

${ }^{113}$ Es muy habitual que Eliano modifique el vocabulario de la fuente a la que sigue. Tanto Wellmann como Richmond, como el mismo De Stefani han incidido en el hecho (cf. KINDSTRAND, J.F., 1997, pp. 2971-2977). Véanse, entre nosotros, las notas de VARA DONADO, J., 1987.

${ }^{114}$ El autor - aparte el esencial pasaje de Pun., XIII, 466-487, ya citado- también menciona la exposición de cadáveres como propia genéricamente de Iberia en el entierro de la reina Asbytes, en el cerco de Sagunto (Pun, II, 265-269), con intención meramente ornamental y patética; e, igualmente, con idéntica pretensión mirífica alude al buitre comedor de cadáveres en XIII, 597 ("Hic dirae uolucres pastusque cadauere vultur"). 


\section{BIBLIOGRAFÍA}

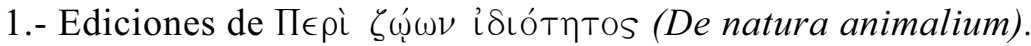

C. GESNER, Zurich, 1556.

C. GESNER, P. GILLIUS, Ginebra, 1616.

A. GRONOVIUS, Londres, 1744.

J.E.G. SCHNEIDER, Leipzig, 1784.

C.F.W. JACOBS, Jena, 1832.

R. HERCHER, París, 1858 (ed. Ambroise F. Didot).

R. HERCHER, Leipzig, 1864 (Bibliotheca Scriptorum Graecorum et Romanorum Teubneriana).

SCHOLFIELD, A.F., Cambridge Mass., 1971 (1958).

En español existen las versiones de

DÍAZ-REGAÑ́́N, J.M., Historia de los animales, Madrid, 1984, Biblioteca Clásica Gredos, 2 vols.

OTERO, ${ }^{\mathrm{a}}$., Historia de los animales, Barcelona, 1987, HyspaméricaOrbis (acrítica, con prólogo de Jorge Luis Borges).

VARA DONADO, J., Historia de los animales, Madrid, 1989, Akal.

2.- Trabajos citados en el texto

ADRADOS, F.R. (1991) (coord.): Diccionario Griego-Español, vol. III, Madrid.

ALFAYÉ VILLA, S. (2001): Pervivencia y cambio en la religión romano-céltica del Occidente del Imperio: los santuarios de la Céltica hispana, Memoria de Licenciatura, Zaragoza.

ALMAGRO GORBEA, M. (2001): "Los celtas en la Península Ibérica", en ALMAGRO GORBEA, M. - MARINÉ, M. - ÁLVAREZ SANCHÍS, J. R. (eds.), Celtas y vetones, Ávila, pp. 94-113.

ALVAR, J.(2001) Los misterios. Religiones "orientales" en el Imperio Romano, Barcelona.

ÁLVAREZ SANCHÍS, J. R. (1999): Los vetones, Madrid.

(2001): "Los vetones", en ALMAGRO GORBEA, M. MARINE, M. - ÁLVAREZ SANCHÍS, J. R. (eds.), Celtas y vettones, Ávila, pp. 259-277.

ANDERSON, G. (1993): The Second Sophistic. A Cultural Phenomenon in the Roman Empire, Londres-Nueva York.

ARANA, J.R. (1999): "La biología de los primeros estoicos", Veleia 16, pp. 233-257.

ARCE, J. (1988): Funus imperatorum. Los funerales de los emperadores romanos, Madrid.

ARNAUD-LINDET, M.P. (2001): Histoire et politique à Rome. Les historiens Romains, IIIe av.J.C.-Ve ap. J.C., París.

ASSMANN, J. (1984): Ägypten. Theologie und Frömmigkeit einer frühen Hochkultur, Stuttgart.

BALIL, A. (1976): Nueva Historia de España en sus textos, Prehistoria y Edad Antigua, Santiago de Compostela.

BALSDON, J.P.V.D. (1979): Romans and Aliens, Londres.

BALTRUSAITIS, J. (1996): La búsqueda de Isis, Madrid. 
Gabriel Sopeña - Vicente Ramón

BARDON, H. (1972): Le goût à l'époque des Flaviens, Latomus 21, Bruselas.

BARRIO VEGA, del, Mª L. (1999) (ed.): Eliano. Cartas rústicas, Madrid, Gredos.

BERNABÉ, A. (1992): Manual de crítica textual y edición de textos griegos, Madrid.

BLÁZQUEZ, J.M. (1962): Religiones primitivas de Hispania I. Fuentes literarias y epigráficas, Madrid.

(1975): Diccionario de las religiones prerromanas de Hispania, Madrid.

(1978): Economía de la Hispania romana, Bilbao.

(1983): Primitivas religiones ibéricas. II. Religiones prerromanas, Madrid.

(1991): Religiones en la España antigua, Madrid.

BONNET, H. (1971): Reallexikon der ägyptischen Religionsgeschichte, Berlín, (1952).

BOWERSOCK, G.W. (1969): Greek Sophist in the Roman World, Oxford.

BOWIE, E.L. (1985): "Elian", en EASTERLING, P.E. - KNOX, B.M.W.(eds.), The Cambridge History of Classical Literature, Cambridge, pp. 680-682.

BRUNAUX, J-L. et alii (1999): "Ribemont-sur-Ancre (Somme). Bilan Préliminaire et nouvelles hypothèses", Gallia 56, pp. 177-283.

BURILLO, F.( 1998): Los celtíberos, etnias y estados, Barcelona.

CANDAU MORÓN, J.M. (1985): "Posidonio y la Historia Universal", Habis XVI, pp. 107-127.

CARO BAROJA, J. (1985): Los pueblos de España, Madrid, (1946), vol, 1.

(1943): "Regímenes sociales y económicos de la España prerromana", Revista Internacional de Sociología, I y II, pp. 149-190 y 285-317. Véase en Ciclos y temas de la Historia de España: España Antigua (conocimiento y fantasías), Madrid, 1986, p. 63.

CARR, G. - KNÜSEL, C. (1997): "The Ritual Framework of Excarnation by Exposure as the Mortuary Practice of the Early and Middle Iron Ages of Central Southern Britain", en GWILT, A. HASELGROVE, C. (eds.), Reconstructin Iron Age Societies. New Approaches to the British Iron Age, Oxford, pp. 167-173.

CLARK, G. (2000): “Animal Passions", Greece \& Rome, 47, 1, pp. 88-93.

COLISH, M.L. (1990): The Stoic Tradition from Antiquity to the Early Middle Ages, I: Stoicism in Classical Latin Literature, Leiden Nueva York - Copenhague - Colonia, (1985).

COSTA, J. (1917): La religión de los celtíberos y su organización política y civil, Madrid (1895).

CRUZ ANDREOTTI, G., (1991): "Schulten y el 'carácter tartesio' “, en ARCE, J. - OLMOS, R., Historiografía de la Arqueología y de la Historia Antigua en España (siglos XVIII-XX), Madrid, pp. 145-148.

CUMONT, F. (1987): Las religiones orientales y el paganismo romano, Madrid, (París, 1905).

(1949): Lux Perpetua, París.

(1966): Recherches sur le symbolisme funéraire des romains, París. 
CUPAIOLO, F. (1973): Itinerario della poesia latina nel primo secolo dell'Impero, Nápoles.

CHAMPEAUX, J. (1982): Fortuna. Le culte de la Fortune à Rome et dans le monde romain, I, Roma.

DAVIES, J. (1999): Death, Burial and Rebirth in the Religions of Antiquity, Londres - Nueva York.

DERCHAIN, Ph. (1997): "Divinidad", en BONNEFOY, Y., Diccionario de las mitologías y de las sociedades tradicionales y del mundo antiguo, Barcelona, (París, 1981), pp. 404-417.

DÍAZ-REGAÑÓN, J.M. (1983): "El estoicismo de Eliano en su Historia animalium", en Unidad y pluralidad en en mundo antiguo, Actas del VI Congreso Español de Estudios Clásicos, II, Madrid, pp. 415-421.

DUCOS, M. (1995): "Le tombeau, Locus religiosus", en HINARD, F. LAMBERT, M.F., La mort au quotidien dans le monde romain, París, pp. 135-144.

DUNAND, F. (1973a): Le culte d'Isis dans le bassin Oriental de la Méditerranée, Leiden, Brill.

(1973b): "Le syncrétisme isiaque à la fin de l'époque hellénistique", en Les syncrétismes dans les religions grecque et romaine, Estrasburgo, pp. 79-93.

DUPLÁ ANSUATEGUI, A. (1993): “ Notas sobre fascismo y mundo antiguo en España", Actas del II Congreso Peninsular de Historia Antigua (Coimbra, 1990), Coimbra, pp. 337-349.

EDELSTEIN, L. (1936): "The Philosophical System of Posidonius", American Journal of Philology 57, pp. 286-325.

EDELSTEIN, L. - KIDD, I.G. (1972): Posidonius, I. The Fragments (Cambridge Classical Texts and Commentaries, 13), Cambridge, (1989).

ELORDUY, E. (1972): El estoicismo, Madrid.

FRANKFORT, H. (1988): Reyes y Dioses, Madrid (Chicago, 1943).

(1999): La religión del Antiguo Egipto, Barcelona, (Chicago, 1948), con estudio, traducción y notas de BALLESTEROS BALBASTRE, F.

GARBARINO, G. (1973): Roma e la filosofia greca dalle origini alla fine del II secolo A.C., 2 vols., Turín.

GARCÍA QUINTELA, M.V. (1990): "Les peuples indigènes et la conquête romaine d'Hispanie. Essai de critique historiographique", DHA 16, 2, pp. 181-210.

(1991) "Sources pour l'étude de la protohistoire d'Hispanie. Pour une nouvelle lecture", DHA 17, 1, pp. 61-99.

(2001): Mitos hispánicos, la Edad Antigua, Madrid.

GIANNINI, A. (1964): "Studi sulla paradossografia greca, II. Da Callimaco all'età imperiale: la letterarura paradossografica", Acme 17, pp. 99-140.

GOLDSCHMIDT, V. (1980): "El estoicismo antiguo", en PARAIN, B.(dir.), Historia de la filosofía (Encyclopédie de la Pléiade, I), Madrid, (París, 1969), pp. 273-314.

GÓMEZ ESPELOSÍN, F.J. (1996) (ed.): Paradoxógrafos griegos, rarezas y maravillas, Madrid. 
GONZÁLEZ-COBOS DÁVILA, A.M ${ }^{\mathrm{a}}$ (1989): Los vacceos. Estudio sobre los pobladores del valle medio del Duero durante la penetración romana, Salamanca.

GREEN, M.A. (2001): Dying for the Gods, Gloucestershire.

GRIMAL,P. (1985): "La religion des stoïciens de Sénèque à MarcAurèle", en Religión, superstición y magia en el mundo romano, Cádiz, pp. 35-48.

(1986): "Quelques aspects du stoïcisme de Lucain dans la Pharsale”, en Rome, la littérature et l'Histoire, vol. I, Roma, pp. 145-157.

HAHM, D.E. (1977): The Origins of Stoic Cosmology, Columbus.

HERCHER, R. (1866) (ed.): Claudii Aeliani Varia Historia. Epistolae fragmenta, Leipzig, Teubner.

HOVEN, R. (1971): Stoicisme et stö̈ciens face au problème de l'au delà, París.

JIMENO, A. (1996): "Numancia: relación necrópolis-poblado", Archivo Español de Arqueología vol. 69, números 173-174, pp. 57-76.

(1999): "Religión y ritual funerario celtibéricos", Revista de Soria 25, pp. 5-18.

(2001): "Numancia", en ALMAGRO GORBEA, M. - MARINÉ, M. - ÁlVAREZ SANCHÍS, J. R. (eds.), Celtas y vettones, Ávila, pp. 239-247.

JIMENO, A. et alii (1996): "Ritual y dieta alimenticia: la necrópolis celtibérica de Numancia", Numantia 6, pp. 31-44.

JUST, M., (1997):"Le teme des disputes entre Héra et Zeus en Arcadie et en Béotie", en Héra. Images, espaces, cultes, Nápoles, pp. 87-92.

KAIBEL, G. (1878): Epigrammata graeca ex lapidis conlecta, Berlín.

KENNEDY, G. (1972): The Art of Rhetoric in the Roman World, Princeton.

KIDD, I.G. (1971): "Posidonius on Emotions", en LONG, A.A. (ed.)., Problems on Stoicism, Londres, capítulo 9.

(1978): "Philosophy and Science in Posidonius", Antike und Abendland, 24, pp. 7-15.

(1988): Posidonius, II. The Commentary, I-II, Cambridge.

(1989): "Posidonius as a Philosopher-Historian", en GRIFFIN, M. - BARNES, J. (eds.), Philosophia Togata. Essays on Philosophy and Roman Society, Oxford, pp. 38-50.

KINDSTRAND, J.F. (1976): "Homer in der Tiergeschichten des Ailianos", Hermes, 104, pp. 35-53.

(1997):"Claudius Aelianus und sein werk", Aufstieg und Niedergang der Römischen Welt (ANRW), II, 34, 4, Berlín, pp. 2954-2996.

KYLE, D.G. ( 2001): Spectacles of Death in Ancient Rome, Londres Nueva York.

LAFFRANQUE, M. (1964): Poseidonios d'Apamée, París.

LAMBOT, B. (1998): "Les morts d'Acy Romance (Ardennes) à La Tène Finale. Pratiques funéraires, aspects religieuses et hiérarchie sociale", Études et documents fouillés, 4. Les Celtes. Rites funéraires en Gaule du Nord entre le Vie et le Ier siècle avant Jesus-Christ, Namur, pp. 75-87.

LAVAGNE, H. (1987): "Le tombeau, mémoire du mort", en La mort, les morts el l'au-delà dans le monde romain, Caen, pp. 159-165. 
LE BOEUFFLE, A. (1989): Le ciel des romains, París.

LECLANT, J. (1979): El mundo egipcio. III: El Egipto del crepúsculo, Madrid.

(1997): "Los cultos isíacos", en BONNEFOY, Y., Diccionario de las mitologías y de las sociedades tradicionales y del mundo antiguo, Barcelona, (París, 1981), pp. 373-389.

LEMBKE, K. (1994): Das Iseum Campense in Rom, Heidelberg.

LESKY, A. (1976): Historia de la literatura griega, Madrid, (Berna, 1963).

LINDERSKI, J. (1986): "Watching the Birds: Cicero the Augur and the Augural Templa", Classical Philology 81, pp. 330-340.

LONG, A.A. (1987): La filosofía helenística, Madrid.

(1996): Stoic Studies, Cambridge.

LONG, A.A. - SEDLEY, D.N. (1987): The Hellenistic Philosophers, Cambridge.

LORRIO, A. (1997): Los celtíberos, Madrid.

(2000): "Grupos culturales y etnias en la Celtiberia", Cuadernos de Arqueología de la Universidad de Navarra 8, pp. 99-180.

LUKINOVICH, A. - MORAND, A.F. (1991) (eds.): Elien. Histoire variée, París, Les Belles Lettres.

MALAGARDIS, N. (1997): "Héra, la sans pareille ou l'épouse exclue? À travers l'image", en Héra. Images, espaces, cultes, Nápoles, pp. 93-112.

MALAISE, M. (1972): Les conditions de pénétration et de difusión des cultes égyptiennnes en Italie, (Études Préliminaires aux Religions Orientales dans l'Empire Romain, 22), Leiden.

(1976): "Histoire et signification de la coiffure hathorique à plumes", Studien zur Altägypt. Kultur 4, pp. 215-236.

(1984): "La difusion des cultes égyptiens dans les provinces européennes de 1'Empire romain", Aufstieg und Niedergang der Römischen Welt (ANRW), II, 17.3, Nueva York - Berlín, pp. 1615-1691.

MALITZ, J. (1983): Die Historien des Poseidonios, Munich.

MARCO SIMÓN, F. (1993): "Feritas Celtica: la imagen del bárbaro clásico”, en FALQUE, E. - GASCÓ, F. (eds.), Modelos ideales y práctica de vida en la Antigüedad clásica, Sevilla, pp. 141-166.

(1998): "Texto e imagen, ethos y creencias en la Hispania indoeuropea de época republicana", en MANGAS, J. (ed.), Italia e Hispania en la crisis de la República romana (Actas del III Congreso Histórico-Arqueológico Hispano-Italiano, Toledo, 1993), Madrid, pp. 387-402.

(1999): "Sacrificios humanos en la Céltica antigua: entre el estereotipo literario y la evidencia interna", Archiv für Religionsgeschichte 1.Band, heft 1, pp. 1-15.

(2000): "La idealización de celtas e hiperbóreos en las fuentes griegas", Dialogues d'Histoire Ancienne 26 (2), pp. 121-147.

MARTIN, J.P. (1982): Prouidentia deorum. Recherches sur certains aspects religieux du pouvoir imperial romain, Roma. 
MEDINA MÍNGUEZ, L. (1998): "Consideraciones sobre el animal en la Historia de los animales de Claudio Eliano", Gallaecia 17, pp. 371-387.

MEKHITARIAN, A. (1978): La peinture égyptienne, Ginebra (1954).

MIKALSON, J.D. (1998): Religión in Hellenistic Athens, Berkeley.

MINICONI, P. - DEVALLET, G. (1979-1984) (eds.), Silius Italicus. La guerre punique, libros I-V, y IX-XIII, París.

MORRIS, I. (1992): Death-Ritual and Social Structure in Classical Antiquity, Cambridge.

NICOL, J. (1936): The Historical and Geographical Sources used by Silius Italicus, Oxford.

NOCK, A.D. (1932): "Cremation and Burial in the Roman Empire", Harvard Theological Review 25, pp. 321-359.

OLMOS, R. (1991): "A. Schulten y la historiografía sobre Tartessos en la primera mitad del siglo XX", en ARCE, J. - OLMOS, R., Historiografía de la Arqueología y de la Historia Antigua en España (siglos XVIII-XX), Madrid, pp. 135-144.

PARKER PEARSON, M. (2000): The Archaeology of Death and Burial, Stroud.

PASAMAR ALZURIA, G. (1986): La historiografía en la España franquista. La posguerra, 1939-1950, Zaragoza.

(1991): Historiografía e ideología en la postguerra española: la ruptura de la tradición liberal, Zaragoza.

PATTERSON, J.R. (2000): "Living and Dying in the City of Rome: houses and tombs", en COULSTON, J. - DODGE, H., Ancient Rome. The Archaeology of the Eternal City, Oxford, pp. 259-289.

PEIRÓ MARTÍN, I. - PASAMAR ALZURIA, G. (1989-90): "El nacimiento en España de la Arqueología y la Prehistoria (Academicismo y profesionalización, 1856-1936)", Kalathos 9-10, pp. 9-30.

PELEGRÍN CAMPO, J. (1994): Barbarie y romanidad, procesos de contacto cultural en el valle medio del Ebro, Memoria de Licenciatura, Universidad de Zaragoza.

PEMBROKE, S.G., "Oikeiosis", en LONG, A.A. (1971) (ed.)., Problems on Stoicism, Londres, pp. 114-149.

PERALTA, E. (2000): Los cántabros antes de Roma, Madrid.

PLÁCIDO, D. (1995): "Emperadores y sofistas: Herodes Ático y Roma", en FALQUE, E. - GASCÓ, F. (eds.), Graecia Capta. De la conquista de Grecia a la helenización de Roma, Huelva, pp. 193-200.

POHLENZ, M. (1948): Die Stoa. Geschichte einer geistigen Bewegung, Gotinga, 2 vols.

PRICE, S. (2000): "Religions of Rome", en COULSTON, J. - DODGE, H., Ancient Rome. The Archaeology of the Eternal City, Oxford, pp. 290-305.

PUENTE OJEA, G. (1979): Ideología e historia. El fenómeno estoico en la sociedad antigua, Madrid.

REARDON, B.P. (1971): Courants littéraires grecs des IIe et IIe siècles aprés J.C., París.

(1974): "The Second Sophistic and the Novel", en BOWERSOCK, G.W. (ed.), Approaches to the Second Sophistic, 
University Park (Pennsylvania), pp. 23-29.

REINHARDT, K. (1921): Poseidonios, Munich.

(1926): Kosmos und Sympathie, Munich.

(1954): Poseidonios von Apamea, der Rhodier Genannt, Stuttgart.

RICHARDSON, J.S. (2000): Appian. Wars of the Romans in Iberia, Warminster.

RICHMOND, J. (1973): Chapters on Greek Fish-Lore, Wiesbaden (Hermes, Einzelschriften, Heft 28).

RIST, J.M. (1985): La filosofía estoica, Barcelona.

ROMERO CARNICERO, F. - SANZ, C. (1997): "Los vacceos, un pueblo en los albores de la historia", en VALDEÓN, J. (dir.), Historia de Valladolid, Valladolid, pp. 23-27.

ROMERO CARNICERO, F. - SANZ, C. - ESCUDERO, Z. (1993) (eds.): Arqueología vaccea. Estudios sobre el mundo prerromano en la cuenca media del Duero, Valladolid.

RUBIO, R. (1996) (ed.): Isis. Nuevas perspectivas (Homenaje al profesor Álvarez de Miranda), Madrid.

RUBIO FERNÁNDEZ, L. (1983): Apuleyo, El asno de oro, Madrid.

RUDOLF, F. (1884): "De fontibus quibus Aelianus in Varia Historia componenda usus sit", Leizpiger Studien zur classichen Philologie 7, pp. $1-138$.

RUIZ VÉLEZ, I. (2001): El ritual funerario en las necrópolis burgalesas de la Edad del Hierro, Burgos.

RUIZ ZAPATERO, G. - LORRIO, A. (1995): "La muerte en el Norte peninsular durante el Primer Milenio a.C." en FÁBREGAS, R. PÉREZ, F. - FERNÁNDEZ, C. (eds.), Arqueoloxía da Morte. Arqueoloxía da morte na Península Ibérica desde as Orixes ata o Medievo, Xinzo de Limia, pp. 223-248.

SACRISTÁN DE LAMA, J.D. (1997): "Buscando a los vacceos en el iberespacio", Kalathos 16, pp. 45-71.

SALINAS DE FRÍAS, M. (2001): Los vettones. Indigenismo y romanización en el occidente de la Meseta, Salamanca.

SAMELLAS, A. (2002): Death in the Eastern Mediterranean (50-600 A.D.), Tubinga.

SANZ MINGUEZ, C. (1998): Los vacceos: cultura y ritos funerarios de un pueblo prerromano del valle medio del Duero. La necrópolis de las Ruedas, Padilla de Duero (Valladolid), Valladolid.

SANZ MÍNGUEZ, C. - MARTÍN VALLS, R. (2001): "Los vacceos", en ALMAGRO GORBEA, M. - MARINE, M. - ÁLVAREZ SANCHÍS, J. R. (eds.), Celtas y vettones, Ávila, pp. 315-325.

SAURON, G. (1994): Quis Deum? L'expression plastique des idéologies politiques et religieuses à Rome à la fin de la République et au début du principat, Roma.

SCHULTEN, A. (1914): Numantia, I, Munich.

(1953): Cincuenta y cinco años de investigación en España, Reus.

(1955): Iberische Landeskunde, Estrasburgo (Geografía y etnografía antiguas de la Península Ibérica, Madrid, 1959, 2 vols.).

SCHULTEN, A.- PERICOT, L. - RUBIO, L. (1959) (eds.): Fontes Hispaniae Antiquae, tomo VIII. Las fuentes desde César hasta el siglo 
$V$ después de Jesucristo, edición de Roberto Grosse, Barcelona.

SCHULTEN, A. - MALUQUER DE MOTES, J. (1987) (eds.): Fontes Hispaniae Antiquae, tomo VII. Hispania Antigua según Pomponio Mela, Plinio el Viejo y Claudio Ptolomeo, edición, índices y traducción por Virgilio Bejarano y prólogo de Joan Maluquer de Motes, Barcelona.

SCHULZ, R. - SEIDEL, M. (1997) (eds.): Egipto, Colonia.

SHARPLES, R.W. (1996): Stoics, Epicureans an Sceptics: an Introduction to Hellenistic Philosophy, Londres.

SIMON, E. (1997): "Héra en Béotie et en Thesalie", en Héra. Images, espaces, cultes, Nápoles, pp. 83-86.

SOPENA, G. (1987): Dioses, ética y ritos, Zaragoza.

(1995): Ética y ritual. Aproximación al estudio de la religiosidad de los pueblos celtibéricos, Zaragoza.

SOPEÑA, G. - RAMÓN PALERM, V. (1994): "El anonimato de un dios de los celtíberos: aportaciones críticas en torno a Estrabón, III, 4, 16", Studia Historica-Historia Antigua XII, pp. 21-34.

SPALSTENSTEIN. F.( 1990): Commentaire des "Punica" de Silius Italicus (vol I: livres 1 à 8. Vol. II: livres 9-à 17), Lausana.

STEFANI, E.L., de (1902): "Il manoscritti della Historia Animalium di Eliano", Studi Italiani di Filologia Classica 10, pp. 175-221.

(1904): "Per L'Epitome Aristotelis de animalibus di Aristofane di Bizancio", Studi Italiani di Filologia Classica 12, pp. 421-445.

STRASBURGER, H. (1965): "Poseidonios on Problems of the Roman Empire", Journal of Roman Studies 55, pp. 40-53.

TAKÁCS, S. (1995): Isis \& Sarapis in the Roman World, Leiden Nueva York - Colonia.

TARACENA, B. (1924): La cerámica ibérica, Madrid.

(1983): Los pueblos celtibéricos, en MENÉNDEZ PIDAL, R. (dir.), Historia de España. Tomo I, volumen 3: España primitiva, la Historia prerromana, Madrid, (1954).

TARDIEU, M. (1997): "La Isis maga en los papiros griegos y coptos", en BONNEFOY, Y., Diccionario de las mitologías y de las sociedades tradicionales y del mundo antiguo, Barcelona, (París, 1981), pp. 389-398.

TIERNEY, J.J. (1960): “The celtic Ethnography of Poseidonius" Proceedings of the Royal Irish Academy 60, pp. 189-246.

TORRE ECHÂVARRI, J. I. de la (1998): "Numancia: usos y abusos de la tradición historiográfica", Complutum 9, pp. 193-211.

TOYNBEE, J.M.C., Death and Burial in the Roman World, Londres, 1971,

TRAN TAM TINH, V. (1990): "Isis", en Lexicon Iconographicum Mythologicae Classicae (LIMC), V, 1, pp. 761-796 (y V, 2, s.v. “Isis"), Zurich - Munich.

TURCAN, R. (1989): les cultes orientaux dans le monde romain, París.

VARA DONADO, J. (1987): “Aportación al conocimiento del texto de la Historia de los animales de Eliano y asuntos conexos", Emerita 55, pp. 97-105. 
VERBEKE, G. (1945): L'évolution de la doctrine du pneuma du stö̈cisme à Saint Augustin, París.

(1973): "Le stoïcisme, une philosophie sans frontières", Aufstieg und Niedergang der Römischen Welt (ANRW), I, 4, Berlín - Nueva York, pp. 3-42.

VERMEULE, E. (1984): La muerte en la poesía y en el arte de Grecia, México D.F., (Berkeley, 1979).

VERNANT, J.P. (1982): "La Belle Mort et le cadavré outragé", en La mort, les morts dans les societés anciennes, Cambridge, pp. 45-76.

VOS, M., de (1980): L'Egittomania in pitture e mosaici romanocampani della Prima Età Imperiale, (EPRO, 84), Leiden.

VIDMAN, L. (1969): Sylloge inscriptionum religionis Isiacae et Sarapiacae, Berlín.

VV.AA. (1992): Alla ricerca di Iside. Analisi, studi e restauri dell'Iseo pompeiano nel Museo di Napoli, Nápoles.

WALBANK, F. (1957-1979): A Historical Commentary on Polibius, 3 vols., Oxford.

WATTENBERG, F. (1959): La región vaccea, Madrid.

(1963): Las cerámicas indígenas de Numancia, Madrid.

WEBSTER, G. (1991): Archaeologist at Large, Londres.

WELLMANN, M. (1891): "Alexander von Mindos", Hermes 2, pp. 481-566.

(1896): “Aegyptisches”, Hermes 31, pp. 221-253.

(1916): "Pamphilos", Hermes 51, pp. 1-64.

WIELAND, G. (1999) (ed.): Keltische Viereckschanzen, Stuttgart.

ZWICKER, I. (1934): Fontes Historiae Religionis Celticae, Berlín.

Gabriel Sopeña Genzor

Universidad de Zaragoza

e-mail:gsopena@posta.unizar.es
Vicente Ramón Palerm

Universidad de Zaragoza e-mail:vmramon@posta.unizar.es 